\title{
Consideration of Future Climatic Changes in Three Geologic Settings
}

G. M. Petrie

September 1984

Prepared for the U.S. Department of Energy under Contract DE-AC06-76RLO 1830

Pacific Northwest Laboratory Operated for the U.S. Department of Energy by Battelle Memorial Institute 


\title{
DISCLAIMER
}

This report was prepared as an account of work sponsored by an agency of the United States Government. Neither the United States Government nor any agency thereof, nor any of their employees, makes any warranty, express or implied, or assumes any legal liability or responsibility for the accuracy, completeness, or usefulness of any information, apparaus, product, or process disclosed, or represents that its use would not infringe privately owned rights. Reference herein to any specific commercial product, process, or service by trade name, trademark, manufacturer, or otherwise, does not necessarily constitute or imply its endorsement, recommendation, or favoring by the United States Government or any agency thereof. The views and opinions of authors expressed herein do not necessarily state or reflect those of the United States Government or any agency thereof.

\author{
PACIFIC NORTHWEST LABORATORY \\ operated by \\ BATTELLE \\ for the \\ UNITED STATES DEPARTMENT OF ENERGY \\ under Contract DE-AC06-76RLO 1830
}

\begin{tabular}{|c|c|}
\hline \multicolumn{2}{|c|}{ Printed in the United States of America } \\
\hline \multicolumn{2}{|c|}{$\begin{array}{c}\text { Available from } \\
\text { National Technical Information Service }\end{array}$} \\
\hline \multicolumn{2}{|c|}{$\begin{array}{l}\text { National Technical Information Service } \\
\text { United States Department of Commerce }\end{array}$} \\
\hline \multicolumn{2}{|c|}{5285 Port Royal Road } \\
\hline \multicolumn{2}{|c|}{ Springfield, Virginia 22161} \\
\hline \\
\hline \multicolumn{2}{|c|}{ Microfiche A01 } \\
\hline \multicolumn{2}{|c|}{ Printed Copy } \\
\hline & Price \\
\hline Pages & Codes \\
\hline $001-025$ & $\mathrm{AO} 2$ \\
\hline 026-050 & A03 \\
\hline $051-075$ & $\mathrm{~A} 04$ \\
\hline $076-100$ & A05 \\
\hline $101-125$ & A06 \\
\hline $126-150$ & $\mathrm{~A} 07$ \\
\hline $151-175$ & $\mathrm{~A} 0 \mathrm{~B}$ \\
\hline $176-200$ & $\mathrm{AOC}$ \\
\hline $201-225$ & $\mathrm{~A} 010$ \\
\hline $226-250$ & A011 \\
\hline $251-275$ & A012 \\
\hline $276-300$ & $\mathrm{~A} 013$ \\
\hline
\end{tabular}


CONSIDERATION OF FUTURE CLIMATIC CHANGES

IN THREE GEOLOGIC SETTINGS

G. M. Petrie

September 1984

Prepared for

the U.S. Department of Energy

under Contract DE-AC06-76RLO 1830

Pacific Northwest Laboratory

Richland, Washington 99352 


\section{EXECUTIVE SUMMARY}

Staff at Pacific Northwest Laboratory are evaluating the potential for climatic change to affect the integrity of a nuclear waste repository at 1) the Gibson Dome area of Utah, 2) the Palo Duro Basin of Texas, and 3) the Gulf Coast. Because a major assumption in this analysis is that a glacial age will recur, the climate of the last glacial period is examined for each location. Combining these paleoclimatic data with the current climatic data, each location is evaluated in light of the criteria given in "Draft Revised General Guidelines For Recommendation of Sites for Nuclear Waste Repositories" (10 CFR 960). The results of this analysis suggest that sites located in these areas are likely to meet the climate requirements set forth in the guidelines. However, further study is needed before a definitive statement can be made. In particular, modeling the effect of sea level change on the Gulf coast groundwater system and obtaining an improved estimation for the increase in recharge during glacier times at the Texas and Utah locations would be useful. Several strategies are presented for accomplishing this work. 
. 


\section{CONTENTS}

EXECUTIVE SUMMARY......................................... ii

inTRODUCTION.............................................. 1

PALEOCLIMATOLOGY.............................................. 3

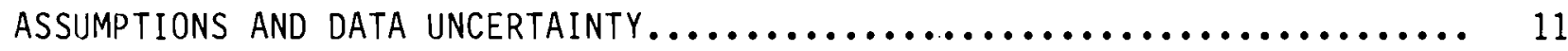

CURRENT CLIMATE AT THE PALO DURO BASIN......................... 21

POSSible FUtURE CLIMATE CONditions AT THE PALO DURO BASIN.............. 33

ANALYSIS OF CLIMATE FOR THE PALO DURO BASIN...................... 35

CURRENT CLIMATE AND METEOROLOGY CONDITIONS AT THE GIBSON DOME.......... 39

POSSIBLE FUTURE CLIMATE CONDITIONS AT THE GIBSON DOME............... 43

ANALYSIS FOR THE GIBSON DOME AREA $, \ldots \ldots \ldots \ldots \ldots \ldots \ldots \ldots \ldots \ldots \ldots \ldots, 47$

CURRENT CLIMATE AND METEOROLOGICAL CONDITIONS AT THE LOUISIANA

AND MISSISSIPPI GULF COAST REGION.............................. 49

POSSIBLE FUTURE CLIMATE CONDITIONS IN THE LOUISIANA AND

MISSISSIPPI GULF COAST REGION................................. 55

ANALYSIS FOR THE LOUISIANA AND MISSISSIPPI GULF COAST REGION.......... 57

CONCLUSIONS AND RECOMMENDATIONS $\ldots \ldots \ldots \ldots \ldots \ldots \ldots \ldots \ldots \ldots \ldots \ldots \ldots \ldots, 61$

REFERENCES.................................................. 63

APPENDIX A - GENERAL GUIDELINES FOR CLIMATE...................... A.I

301930 
FIGURES

1 Areas Considered for the Possible Location of a Nuclear Waste Repository in Salt.................................. 2

2 Extent of Continental Glaciation........................ 5

3 Summary of Estimated Summer Temperatures $\left({ }^{\circ} \mathrm{C}\right)$ and Changes in Annual Precipitation for 18,000 year B.P..................... 6

4 Distribution of Pluvial Lakes Within the Great Basin and Elsewhere in the Western United States known or Inferred To Have Expanded During the Period 10,000 to 25,000 year B.P.................. 7

5 Precession of the Equinoxes................................. 13

6 The Longitude of the Perihelion Given by the Sum of the

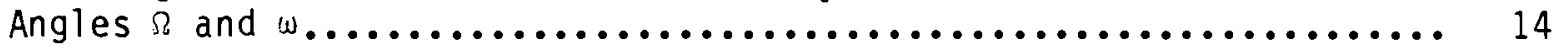

7 Predicted Values of Obliquity of the Earth's Axis for the Next Million Years Based on the Solutions of Berger................. 15

8 Predicted Values of Eccentricity of the Earth's Orbit for the Next Million Years Based on the Solutions of Berger.............. 16

9 Predicted Values of the Longitude of Perihelion of the Earth's Orbit for the Next One Million Years Based on the Solutions

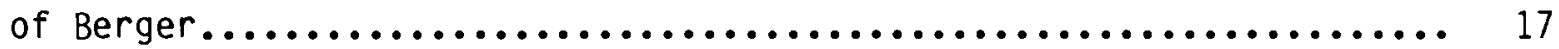

10 Climate Forecast for the Next 25,000 Years. ....................... 19

11 Range of Precipitation at Amaril10....................... 22

12 Range of Precipitation at Lubbock........................ 23

13 Average Annual Precipitation Across Texas...................... 24

14 Percentage Frequency of Thunderstorms in the Region of the Palo Duro Basin, Based on Hourly Observations................. 25

15 Rainfall Stations Within the Texas Panhandle Study Area........... 26

16 Isohyetal Map Based on 24-hour Rainfall Ending

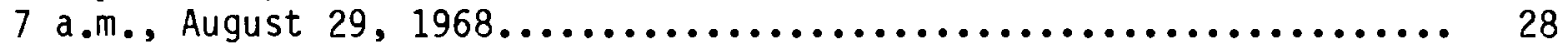

17 Range of Temperature at Amari110......................... 29

18 Range of Temperature at Lubbock........................ 30 
19 Annual Temperature Across Texas............................ 31

20 Curves Depicting the Relationship Between Mean Annual Sediment Yield and Mean Annual Precipitation at Various Mean Annual

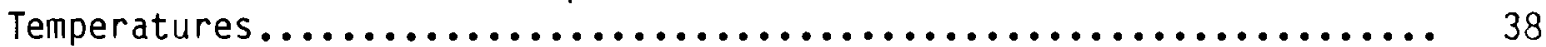

21 Range of Temperature at Moab, Utah....................... 40

22 Range of Precipitation at Moab, Utah..................... 41

23 Annual Wind Means for Green River........................ 42

24 Range of Temperature Near Richton Dome, Mississippi............. 50

25 Range of Temperature Near Vacherie Dome, Louisiana.............. 51

26 Range in Precipitation Near Richton Dome, Mississippi........... 52

27 Range in Precipitation Near Vacherie Dome, Louisiana............. 53 


\section{TABLES}

1 Geologic Time Scale Summarizing the Earth's Climate During the Past 600 Million Years.................................. 4

2 Pluvial Lakes in the Western United States witr RadiocarbonDated Chronologies in the Range of 25,000 to 10,000 year B.P...... 8

3 Depth-Frequency Relationships for 24-hour Rainfall for Stations in the Texas panhandle................................... 27

4 Estimated Evapotranspiration for Types of Vegetation in the Western United States................................. 37

5 Paleoclimatic Reconstruction for the Full Glacial of the American Southwest.................................. 44 


\section{INTRODUCTION}

The purpose of this report is to discuss the potential for future climatic changes to affect the integrity of a potential nuclear waste repository located in 1) Gibson Dome area of Utah, 2) the Palo Duro Basin of Texas, and 3) the Gulf Coast region of Mississippi and Louisiana (Figure 1). The revised draft guidelines (see Appendix A) (DOE 1983) set forth the requirements that a repository must meet to be acceptable. Future climatic changes are of obvious concern because they can affect a number of important factors, such as groundwater recharge, erosion, and salt dissolution at the site.

Climate is a dynamic system and subject to change. Mitchell (1977a) states:

The climate of the earth is now known beyond any doubt to have been in a more or less continual state of flux. Changeability is evidently a characteristic of climate on all resolvable time scales of variation, from that of aeons down to those of millennia and centuries. The lesson of history seems to be that climatic variability must be recognized and dealt with as a fundamental quality of climate and that it would be potentially perilous for modern civilization to assume that the climate of future decades and centuries will be free of similar variability.

To address the above considerations, this report first presents a short and very general discussion of past climatic conditions. This is followed by a section on the assumptions used and data uncertainty. With this background, each of the three areas is discussed separately, and conclusions and recommendations are then given. 


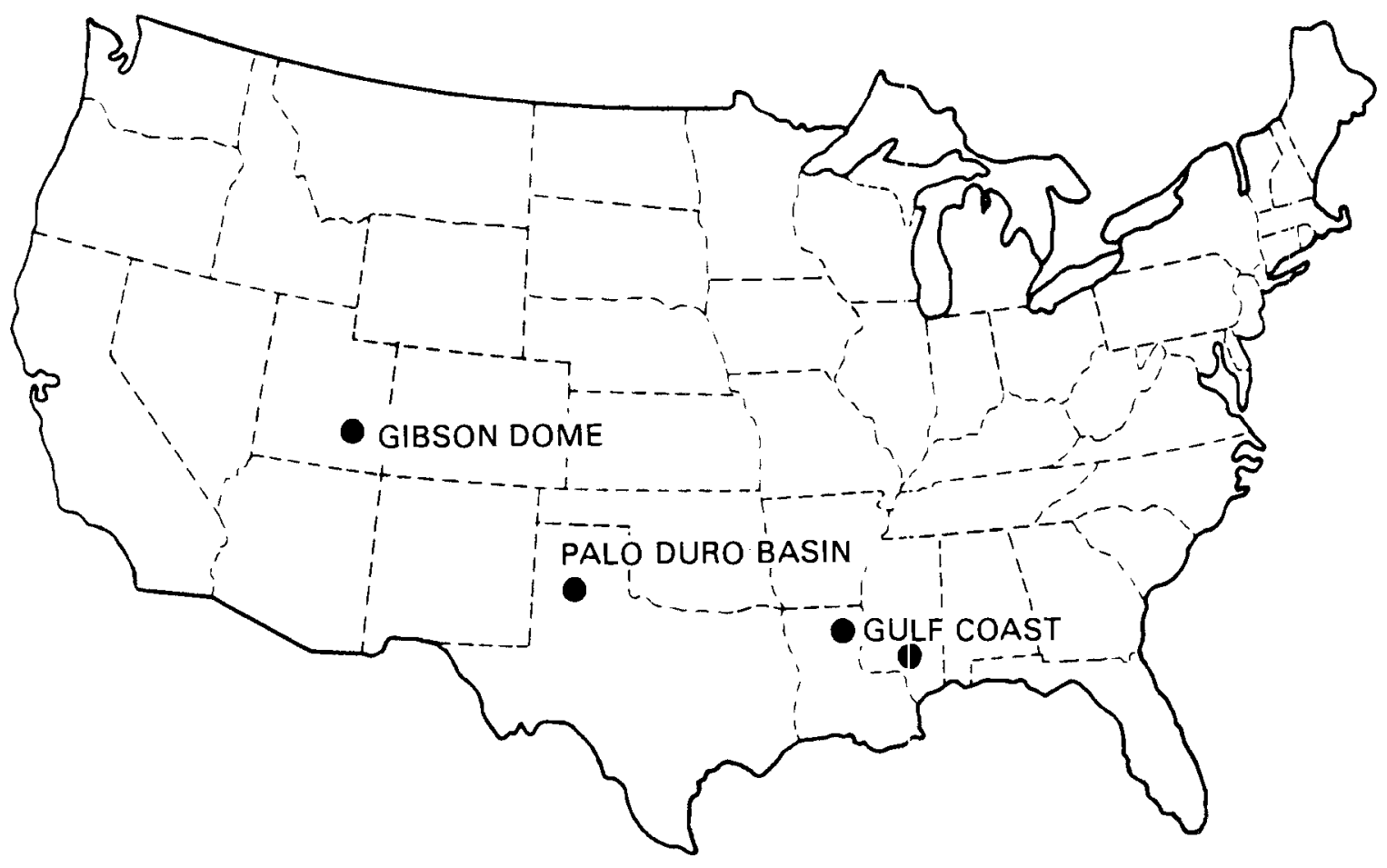

FIGURE 1. Areas Considered for the Possible Location of a Nuclear Waste Repository in Salt 


\section{PALEOCLIMATOLOGY}

Geologic evidence supports the view that global climate over the past billion years was much warmer (perhaps $10^{\circ} \mathrm{C}$ ) than the current climate, with the exception of a few relatively short ice-age intervals (Mitchell 1977a). During most of this time, the earth was entirely free of polar ice. However, during the Cenozoic Era (Table 1)--approximately 65 million years ago--the earth began to cool gradually. By the late Cenozoic, glacial ice repeatedly spread from northeastern Canada into middle-latitude regions of the United States and extended into the mountainous area of the West (Figure 2). These glacial stages were separated by warm interglacial stages.

Figure 3 summarizes the anomalies of summer climate at the last glacier maximum [around 18,000 years before present (B.P.)] inferred from biologic and geologic evidence. Nearly all of the continental United States, with the exception of the Southwest and perhaps the Great Basin, was both colder and drier than it is at present. The best evidence for increased moisture in the Southwest (Antevs 1954; Galloway 1983; Snyder and Langbein 1962; Spaulding 1977, 1980; Van Devender 1977; Wells 1966, 1979; Wendorf 1961; Winograd and Doty 1980) was the formation of large lakes (Figure 4 and Table 2) and the extension of woodland plants into what are now arid and semiarid regions. For example, juniper grew at altitudes as much as $600 \mathrm{~m}$ lower than altitudes where juniper is currently found in Nevada (Winograd and Doty 1980).

With the end of the Wisconsin glaciation, the climate entered its current interglacial stage. The warmest part of the interglacial stage, termed the Altithermal period, occurred 4,500 to 8,500 years ago (Cole 1980), and the midlatitude temperatures have been slowly decreasing since then. 
TABLE 1. Geologic Time Scale Summarizing the Earth's Climate During the Past 600 Million Years. In the distant past the climate was generally warmer than it is today, although evidence exists that there were ice sheets during parts of the Precambrian Era and the Ordovician and Permocarboniferous Periods.

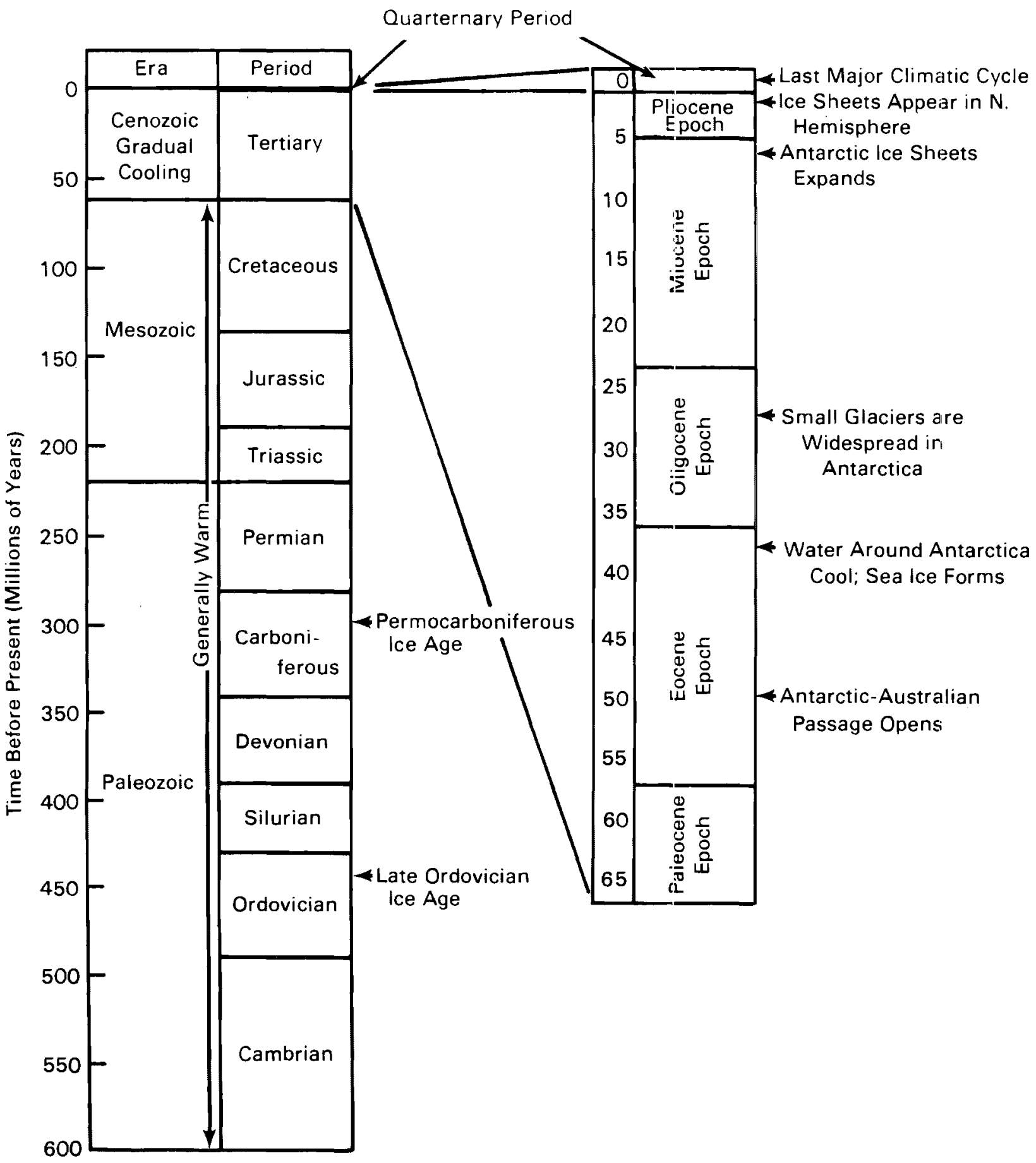




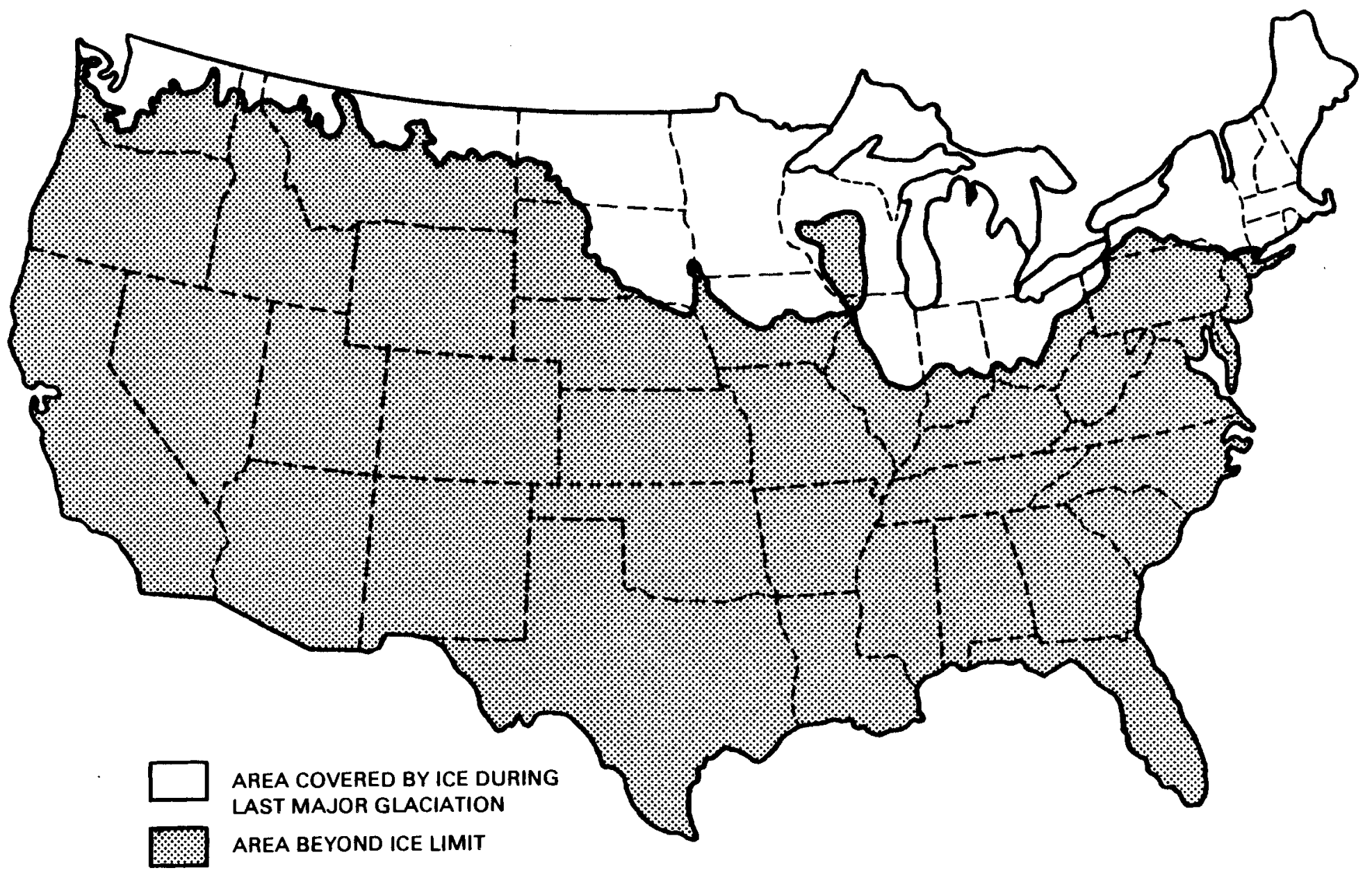

FIGURE 2. Extent of Continental Glaciation (modified from Flint 1971) 


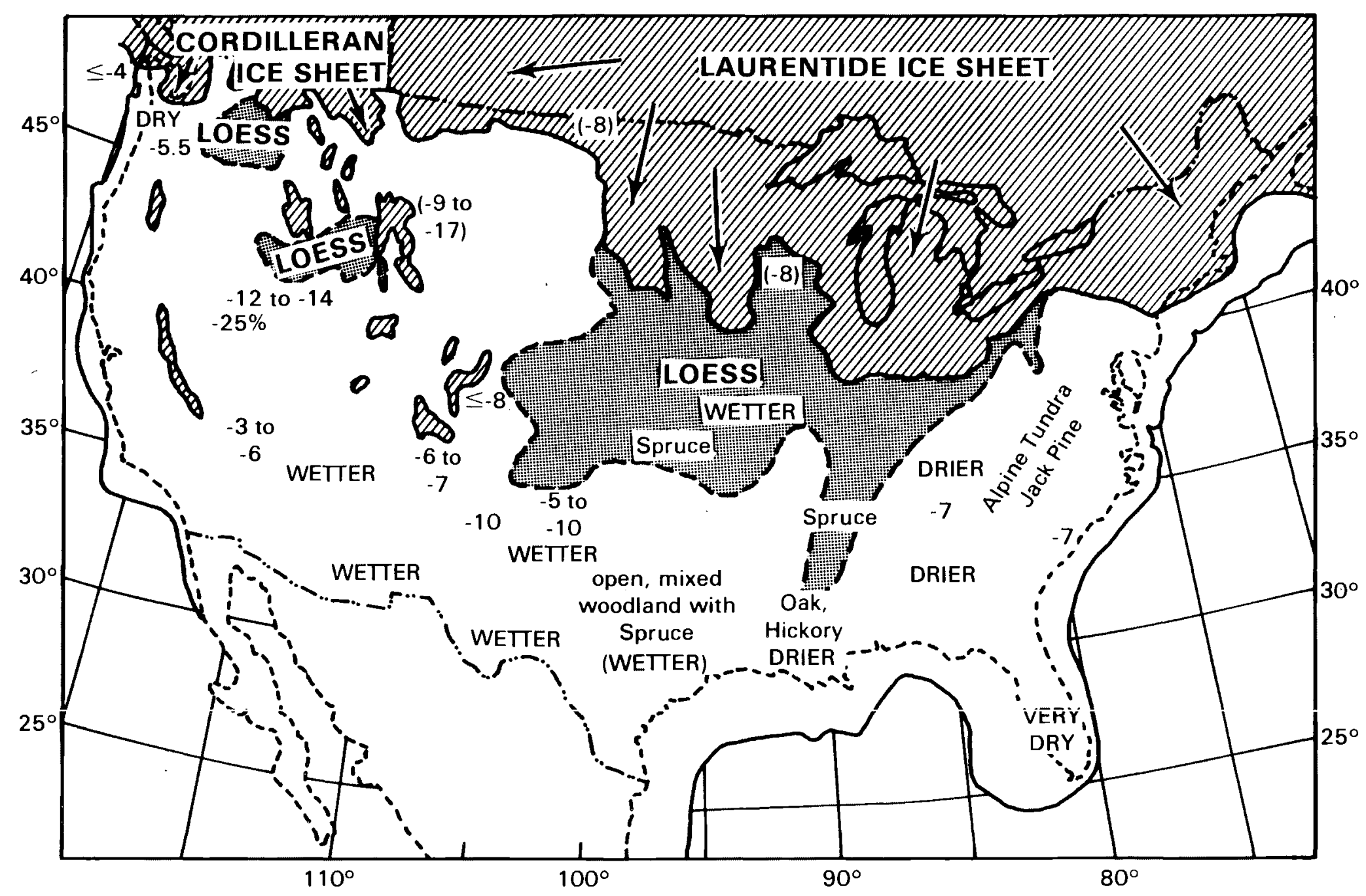

FIGURE 3. Summary of Estimated Summer Temperatures $\left({ }^{\circ} \mathrm{C}\right)$ and Changes in Annual Precipitation for 18,000 year B.P. Shown in relation to other paleoenvironmental data. In a few cases, mean annual temperature (in centigrade) estimates are shown in parenthesis (modified from Barry 1983) 


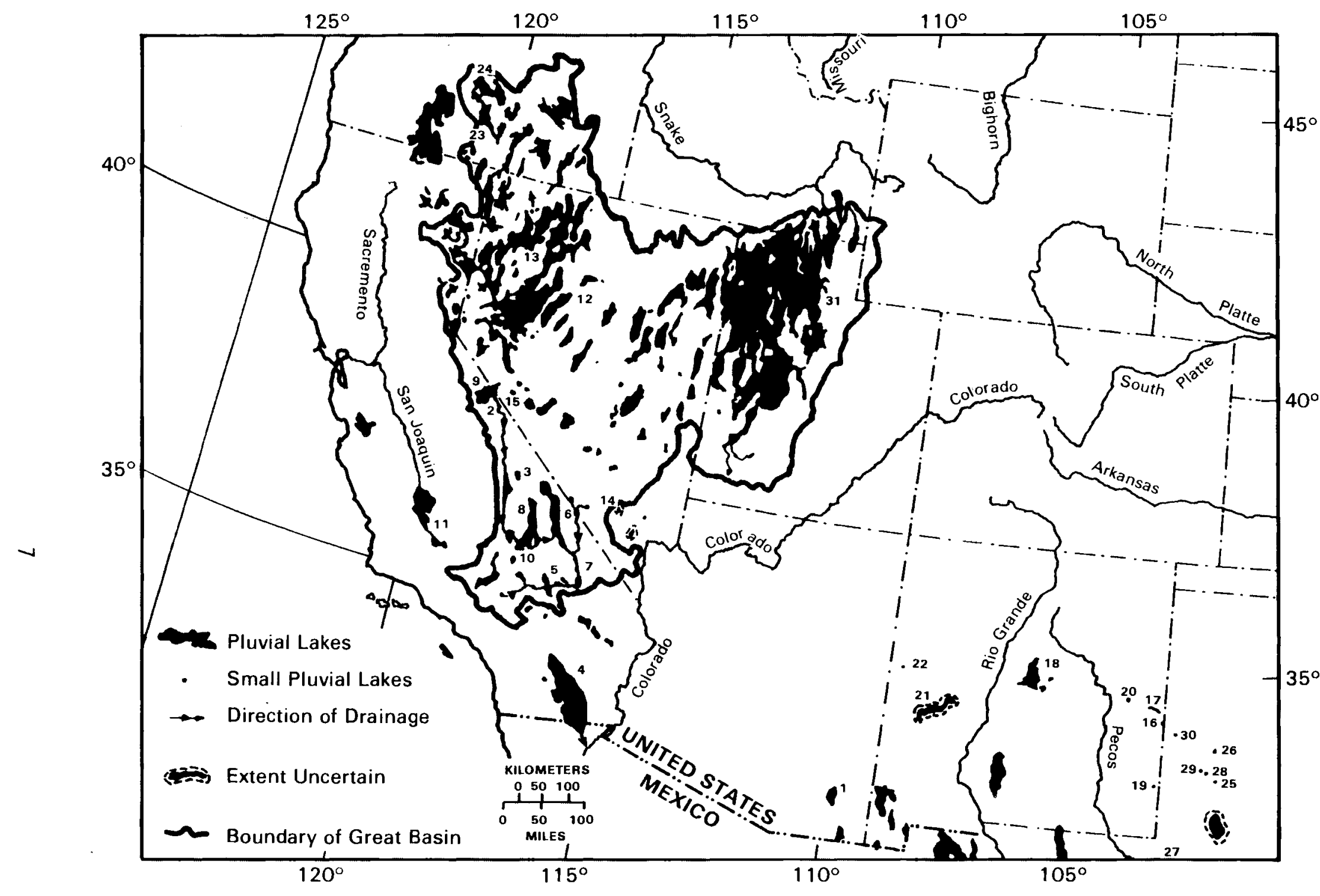

FIGURE 4. Distribution of Pluvial Lakes Within the Great Basin (outlined) and Elsewhere in the Western United States Known or Inferred To Have Expanded During the Period 10,000 to 25,000 year B.P. The numbered lakes are listed in Table 2 (modified from Smith and Strict-Perrott 1983). 
TABLE 2. Pluvial Lakes in the Western United States with RadiocarbonDated Chronologies in the Range of 25,000 to 10,000 year B.P. (modified from Smith and Strict-Perrott 1983)

\begin{tabular}{|c|c|c|c|c|c|}
\hline $\begin{array}{c}\text { State/ } \\
\text { Lake Number } \\
\end{array}$ & $\begin{array}{l}\text { Pluvial Lake (name of } \\
\text { modern lake, playa or } \\
\text { valley, if different) }\end{array}$ & $\begin{array}{l}\text { Lat itude } \\
\left({ }^{\circ} \mathrm{N}\right) \\
\end{array}$ & $\begin{array}{c}\text { Longitude } \\
\left({ }^{\circ} \mathrm{W}\right)\end{array}$ & $\begin{array}{l}\text { Maximum } \\
\text { area }\left(\mathrm{km}^{2}\right) \\
\end{array}$ & $\begin{array}{l}\text { Maximum increase } \\
\text { in depth relative } \\
\text { to present (m) }\end{array}$ \\
\hline \multicolumn{6}{|l|}{ Arizona } \\
\hline 1 & Cochise (Willcox) & $32^{\circ} 08^{\prime}$ & $109^{\circ} 51^{\prime}$ & 310 & 26 \\
\hline \multicolumn{6}{|l|}{ California } \\
\hline 2 & Adobe (Black Lake) & $37^{\circ} 55^{\prime}$ & $118^{\circ} 36^{\prime}$ & 52 & 24 \\
\hline 3 & Deep Spring & $37^{\circ} 17^{\prime}$ & $118^{\circ} 02^{\prime}$ & ca. 44 & unkngwn (a) \\
\hline 4 & Le Conte (Salton Sea) & $33^{\circ} 20^{\prime}$ & $116^{\circ} 00^{\prime}$ & ca. 4600 & $>85^{(D)}$ \\
\hline 5 & $\begin{array}{l}\text { Manix (Troy Lake, } \\
\text { Coyote Lake) }\end{array}$ & $35^{\circ} 03^{\prime}$ & $116^{\circ} 42^{\prime}$ & 407 & 116 \\
\hline 6 & $\begin{array}{l}\text { Manly (Death Valley } \\
\text { Salt Pan, Badwater) }\end{array}$ & $36^{\circ} 00^{\prime}$ & $116^{\circ} 48^{\prime}$ & 1600 & 183 \\
\hline 7 & $\begin{array}{l}\text { Major (Soda Lake, } \\
\text { Silver Lake) }\end{array}$ & $35^{\circ} 22^{\prime}$ & $116^{\circ} 08^{\prime}$ & ca. 200 & $>12$ \\
\hline 8 & Panamint & $36^{\circ} 18^{\prime}$ & $117^{\circ} 18^{\prime}$ & 722 & $283^{(c)}$ \\
\hline 9 & Russell (Mono Lake) & $38^{\circ} 03^{\prime}$ & $118^{\circ} 46^{\prime}$ & 692 & 238 \\
\hline 10 & $\begin{array}{l}\text { Searles (China Lake } \\
\text { Searles Lake) }\end{array}$ & $35^{\circ} 03^{\prime}$ & $117^{\circ} 42^{\prime}$ & 994 & 196 \\
\hline 11 & $\begin{array}{l}\text { Tulare (Kern, Buena } \\
\text { Vista, and Tulare } \\
\text { Lakes) }\end{array}$ & $36^{\circ} 00^{\prime}$ & $119^{\circ} 40^{\prime}$ & ca. 4100 & ? (d) \\
\hline \multicolumn{6}{|l|}{ Nevada } \\
\hline 12 & $\begin{array}{l}\text { Dixie (Humboldt } \\
\text { Salt Marsh) }\end{array}$ & $39^{\circ} 55^{\prime}$ & $117^{\circ} 60^{\prime}$ & 1088 & 72 \\
\hline 13 & $\begin{array}{l}\text { Lahontan (Pyramid, } \\
\text { Walker and Honey Lakes; } \\
\text { Carson Sink; Winnemucca } \\
\text { Smoke Creek, Black Rock, } \\
\text { Desert Valley, and } \\
\text { Buena Vista Basins) }\end{array}$ & $40^{\circ} 00^{\prime}$ & $119^{\circ} 30^{\prime}$ & 22,400 & $160^{(e)}$ \\
\hline $\begin{array}{l}14 \\
15\end{array}$ & $\begin{array}{l}\text { Las Vegas } \\
\text { Teel (Teels Marsh) }\end{array}$ & $\begin{array}{l}36^{\circ} 19^{\prime} \\
38^{\circ} 12^{\prime}\end{array}$ & $\begin{array}{l}115^{\circ} 11^{\prime} \\
118^{\circ} 21^{\prime}\end{array}$ & $\begin{array}{l}\text { unknown } \\
\text { unknown }\end{array}$ & $\begin{array}{l}\text { unknown } \\
\text { unknown }\end{array}$ \\
\hline \multicolumn{6}{|l|}{ New Mexico } \\
\hline 16 & $\begin{array}{l}\text { Arch (Big Salt Lake, } \\
\text { Laguna Salada) }\end{array}$ & $34^{\circ} 04^{\prime}$ & $103^{\circ} 07^{\prime}$ & ca. 130 & $>12$ \\
\hline $\begin{array}{l}17 \\
18\end{array}$ & $\begin{array}{l}\text { Blackwater Draw } \\
\text { Estancia (Laguna } \\
\text { del Perro, Salina } \\
\text { Lake, etc) }\end{array}$ & $\begin{array}{l}34^{\circ} 15^{\prime} \\
34^{\circ} 45^{\prime}\end{array}$ & $\begin{array}{l}103^{\circ} 20^{\prime} \\
106^{\circ} 00^{\prime}\end{array}$ & $\begin{array}{l}\text { unknown } \\
2860^{n}\end{array}$ & $\begin{array}{l}\text { unknown } \\
90\end{array}$ \\
\hline 19 & Lea County & $33^{\circ} 27^{\prime}$ & $103^{\circ} 09^{\prime}$ & $\begin{array}{l}\text { uncertain } \\
\text { (small) }\end{array}$ & $\begin{array}{l}\text { uncertain } \\
\text { (small) }\end{array}$ \\
\hline
\end{tabular}


TABLE 2. (contd)

\begin{tabular}{|c|c|c|c|c|c|}
\hline $\begin{array}{c}\text { State/ } \\
\text { Lake Number } \\
\end{array}$ & $\begin{array}{l}\text { Pluvial Lake (name of } \\
\text { modern lake, playa or } \\
\text { valiey, if different) }\end{array}$ & $\begin{array}{c}\text { Latitude } \\
\left({ }^{\circ} \mathrm{N}\right) \\
\end{array}$ & $\begin{array}{c}\text { Longitude } \\
\left({ }^{\circ} \mathrm{W}\right)\end{array}$ & $\begin{array}{l}\text { Maximum } \\
\text { area }\left(\mathrm{km}^{2}\right) \\
\end{array}$ & $\begin{array}{l}\text { Maximum increase } \\
\text { in depth relative } \\
\text { to present (m) }\end{array}$ \\
\hline 20 & Portales Valley & $34^{\circ} 26^{\prime}$ & $103^{\circ} 49^{\prime}$ & $\begin{array}{l}\text { unknown } \\
\text { (smal1) }\end{array}$ & $\begin{array}{l}\text { unknown } \\
\text { (smpli) }\end{array}$ \\
\hline 21 & $\begin{array}{l}\text { San Augustin } \\
\text { (San Augustin Playa) }\end{array}$ & $33^{\circ} 50^{\prime}$ & $108^{\circ} 10^{\prime}$ & 660 & $50^{(t)}$ \\
\hline 22 & Zuni & $34^{\circ} 27^{\prime}$ & $108^{\circ} 46^{\prime}$ & 5 & 15 \\
\hline \multicolumn{6}{|l|}{ Oregon } \\
\hline 23 & $\begin{array}{l}\text { Chewaucan (Abert Lake } \\
\text { Summer Lake) }\end{array}$ & $42^{\circ} 40^{\prime}$ & $120^{\circ} 30^{\prime}$ & 1240 & 115 \\
\hline 24 & $\begin{array}{l}\text { Fort Rock (Silver Lake, } \\
\text { Christmas Lake, Fossil } \\
\text { Lake) }\end{array}$ & $43^{\circ} 10^{\prime}$ & $120^{\circ} 45^{\prime}$ & 3885 & 49 \\
\hline \multicolumn{6}{|l|}{ Texas } \\
\hline 25 & Guthrie & $33^{\circ} 06^{\prime}$ & $101^{\circ} 54^{\prime}$ & $\begin{array}{l}\text { unknown } \\
\text { (smal1) }\end{array}$ & $\begin{array}{l}\text { unknown } \\
\text { (small) }\end{array}$ \\
\hline 26 & Lubbock & $33^{\circ} 38^{\prime}$ & $101^{\circ} 54^{\prime}$ & $\begin{array}{l}\text { unknown } \\
\text { (smal 1) }\end{array}$ & $\begin{array}{l}\text { unknown } \\
\text { (small) }\end{array}$ \\
\hline 27 & Monahans Dunes & $31^{\circ} 36^{\prime}$ & $102^{\circ} 53^{\prime}$ & unknown & unknown \\
\hline 28 & Mound & $33^{\circ} 05^{\prime}$ & $102^{\circ} 53^{\prime}$ & unknown & unknown \\
\hline 29 & Rich & $33^{\circ} 17^{\prime}$ & $102^{\circ} 12^{\prime}$ & $\begin{array}{l}\text { unknown } \\
\text { (small) }\end{array}$ & $\begin{array}{l}\text { unknown } \\
\text { (small) }\end{array}$ \\
\hline 30 & White & $\mathrm{ca} .33^{\circ} 58^{\prime}$ & $102^{\circ} 44^{\prime}$ & $\begin{array}{l}\text { unknown } \\
\text { (small) }\end{array}$ & $\begin{array}{l}\text { unknown } \\
\text { (smal1) }\end{array}$ \\
\hline \multicolumn{6}{|l|}{ Utah } \\
\hline 31 & $\begin{array}{l}\text { Bonneville (Great } \\
\text { Salt, Utah, and } \\
\text { Sevier Lakes; Great } \\
\text { Salt Lake and Escalante } \\
\text { Deserts; Cache, Sevier, } \\
\text { white, and Rush Valleys) }\end{array}$ & $40^{\circ} 30^{\prime}$ & $113^{\circ} 00^{\prime}$ & 51,640 & ca. 335 \\
\hline
\end{tabular}

(a) The former lake depth is impossible to reconstruct because of poor lacustrine record.

(b) The lake basin has been strongly affected by faulting and tilting, so the latePleistocene configuration is difficult to reconstruct accurately.

(c) Highest shoreline remnants dated suggest a maximum depth of 298 in.

(d) Depths of large late-Pleistocene and early-Holocene lakes are uncertain because of structural downwarping and changes in the height of the alluvial-fan barriers separating the present lake basins, but they probably were shallow.

(e) Measured from natural (preirrigation) level of Pyramid Lake (1180 m).

(f) Highest shoreline remnants dated suggest a maximum depth of $69 \mathrm{~m}$. 
- 


\section{ASSUMPTIONS AND DATA UNCERTAINTY}

Predicting the climate of a site for the next 10,000 years is a difficult task; however, rough estimates are possible using information from the geologic record and current trends. Looking at the past geologic record may be particularly informative because the current interglacial climate might revert to a new ice age. The last period of continental glaciation in North America started approximately 2.5 to 3 million years ago and may have not yet ended; the present can be viewed as a warm interval in the apparently cyclic pattern where continental and mountain glaciers expanded and contracted. Evidence of other glacial periods, each of which may have lasted on the order of 10 to 90 million years, is found throughout the geologic record. For example, the last Precambrian Varagian ice age lasted for about 20 million years; the Ordovician, about 25 million years; and the Permocarboniferous, about $50 \mathrm{mi1}$ lion years (Table 1) (Harland and Herod 1975; Wright and Moseley 1975; John $1979 a, b)$. Thus, the past 2.5 million years may be merely a prologue to a longterm glacial period.

The duration of past interglacial periods can provide a guide to the expected time remaining in the current interglacial stage, which began with the decay of of the last ice sheet approximately 10,000 years ago. Using the oxygen isotope ratios (which, as described below, are a function of glacier ice volume) found in deep-sea cores as a guide, Imbrie and Imbrie (1979) found that no Pleistocene interglacial lasted more than 12,000 years and that most have lifespans of about 10,000 years. Thus, the current interglacial may be coming to an end within the next 2,000 years. Therefore, it is appropriate to consider the effects of a new glacial age at a potential nuclear waste repository.

Theoretical considerations also suggest that it is appropriate to consider the effects of a new glacial age. Following the pioneering work of Milankovitch (1920) and Croll (1875), an increasing body of evidence (e.g., Hays et al. 1976; Imbrie and Imbrie 1979, 1980; Cess and Wronka 1979) indicates that the Milankovitch Theory of climatic fluctuations is an important factor in explaining climatic fluctuations in the late Cenozoic. The underlying premise of this model is that the gross climatic variations (of an amplitude sufficient 
to create major glacial ice sheets on the earth's surface at high latitudes) are driven by variations in the primary orbital elements of the earth. Specifically, three quantities of 1) obliquity, 2) eccentricity, and 3) longitude of perihelion are needed to specify the earth's orbit for the purpose of discussing climate change.

Obliquity is the angle of tilt of the earth's axis with respect to the plane of its orbit; the obliquity today is 23.5 degrees. The earth undergoes seasonal changes mainly because the axis of its rotation is tilted. During June, July, and August the Northern Hemisphere points toward the sun and receives more sunlight than it would if the axis were perpendicular to the plane of the orbit; the Southern Hemisphere receives less sunlight. Six months later, when the earth has moved 180 degrees along its orbit, the situation is reversed. Eccentricity measures the departure of the orbit from a perfect circle. A circle has zero eccentricity, and an ellipse twice as long as it is wide has an eccentricity of 0.866. At present the eccentricity of the earth's orbit is 0.017 . Eccentricity modifies the seasonal cycle slightly.

Because the earth's orbit is an ellipse rather than a circle, the distance from the earth to the sun varies with the time of year. In January the earth is closest to the sun (perihelion) and in July it is farthest from it (aphelion). Accordingly, the global insolation is slightly greater in January than it is in July. This effect gives the Northern Hemisphere warmer winters and cooler summers than the hemisphere would have if the earth's orbit were circular. The earth's axis of rotation also moves slowly around a circular path and completes one revolution every 26,000 years. For instance, although the axis currently points toward Polaris, in 4000 B.C. it pointed to the tip of the handle of the Big Dipper. This precession causes the vernal equinox (and the other three cardinal points) to move slowly around the orbital path. To an observer looking down on the North Pole, the direction of this movement would appear to be clockwise. Simultaneously, the elliptical orbit itself is rotating, independently and much more slowly, in a counterclockwise direction in the same plane. Together, the two movements cause the point of each of the 
cardinal points to shift along the orbit (Imbrie and Imbrie 1979) (Figure 5). A measure of this movement is called the longitude of perihelion which is defined in Figure 6.

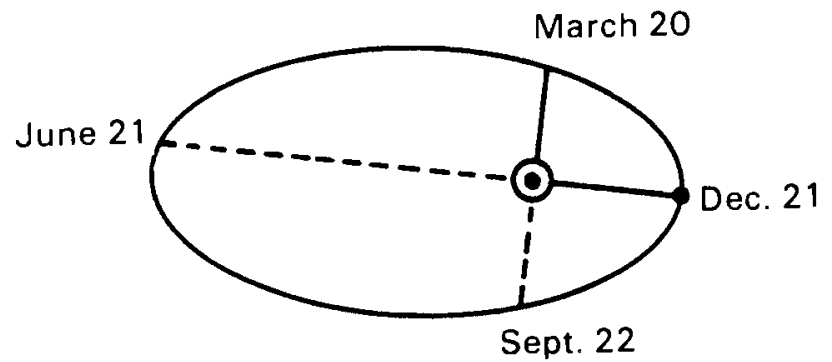

Today

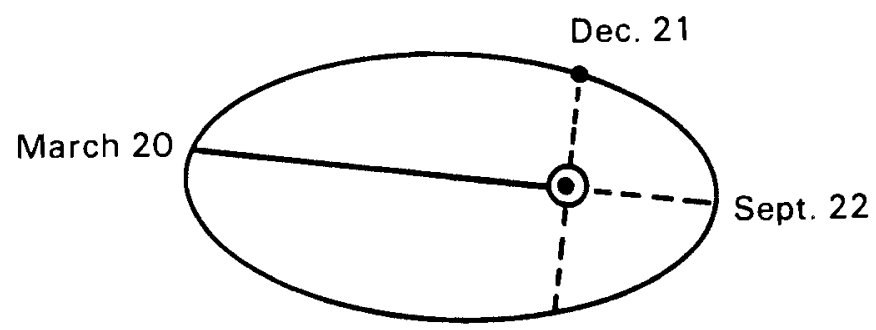

5,500

Years

Ago

June 21

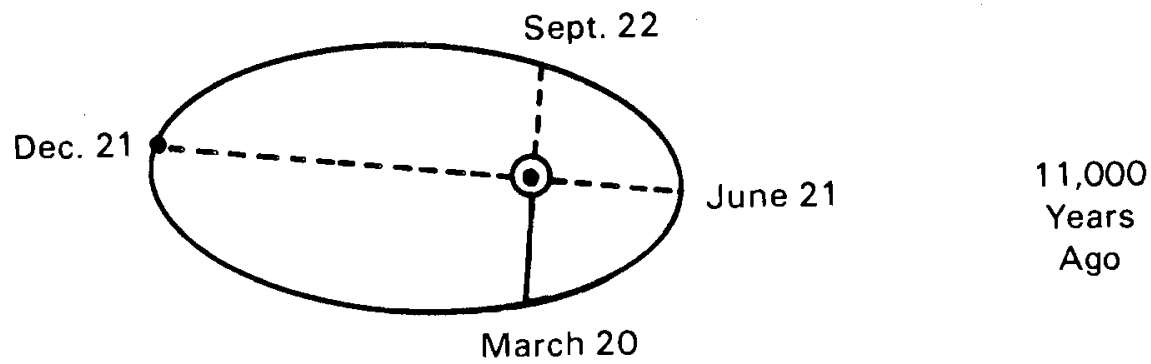

- Earth on Dec. 21

○ Sun

FIGURE 5. Precession of the Equinoxes. Owing to axial precession and to other astronomical movements, the positions of equinox (March 20 and September 22) and solstice (June 21 and December 21) shift slowly around the earth's elliptical orbit, and complete one full cycle about every 22,000 years. Eleven thousand years ago, the summer solstice occurred near one end of the orbit. Today, the summer occurs near the opposite end of the orbit. As a result, the earth-sun distance, measured on December 21, changes (modified from Imbrie and Imbrie 1979). 


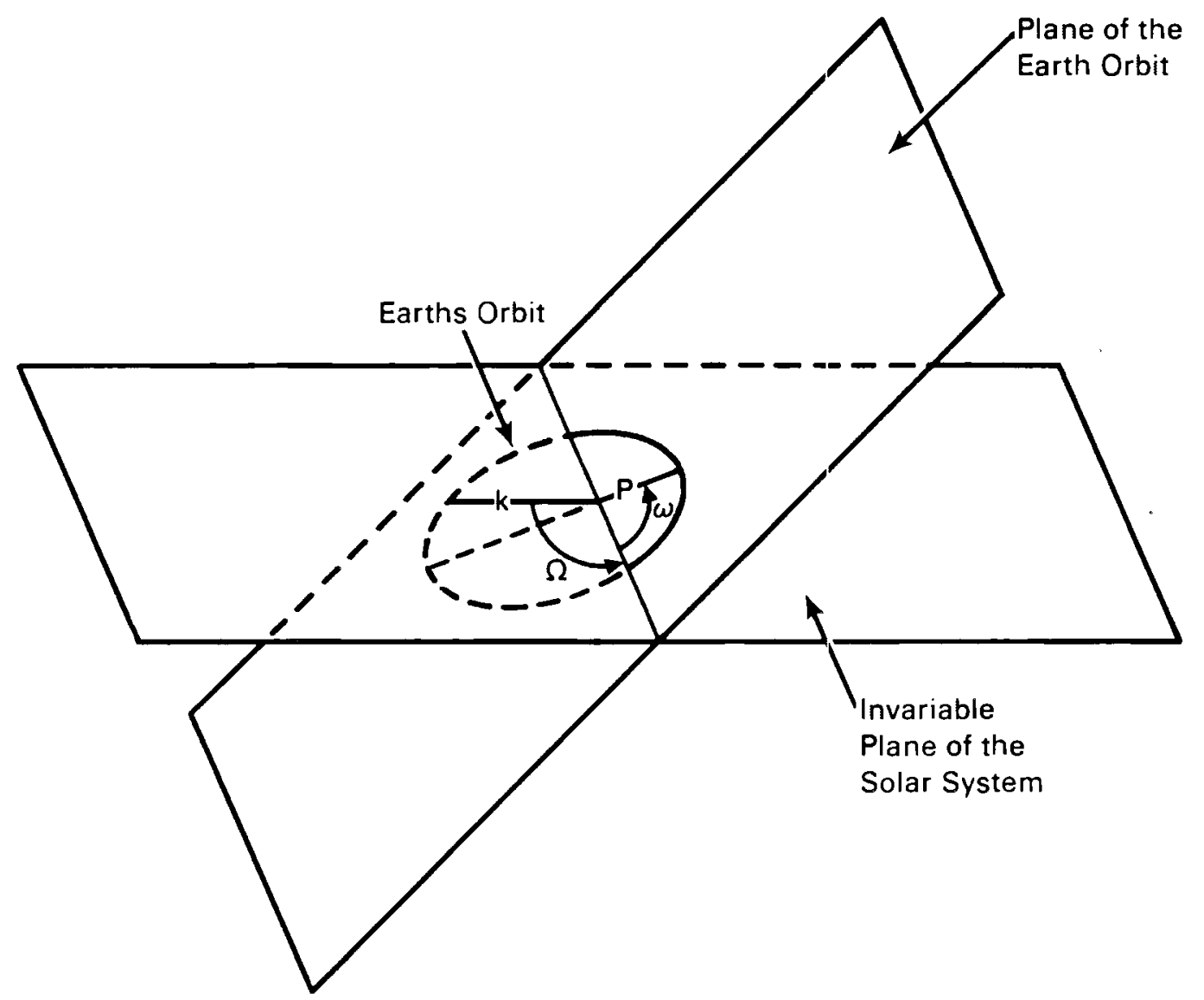

FIGURE 6. The Longitude of the Perihelion Given by the Sum of the Angles $\Omega$ and $\omega$. $P$ is a line joining the sun and the perihelion, and $k$ is a line joining the sun and the projection of the vernal equinox.

All three parameters are subject to change with time as a result of the small gravitational pull of the moon and other planets. The tilt of the earth's axis varies between 22.1 and 24.5 degrees with a period of about 40,000 years (Figure 7). The eccentricity of the orbit varies between amount 0.005 and 0.06 with a period of about 100,000 years (Figure 8 ). The longitude of perihelion has a period of about 22,000 years (Figure 9 ).

In the Milankovitch theory a key factor in the earth's climate is believed to be not the total amount of sunlight received by the planet in a years time, but rather the distribution of sunlight at high latitudes in the northern hemisphere during the summer. 


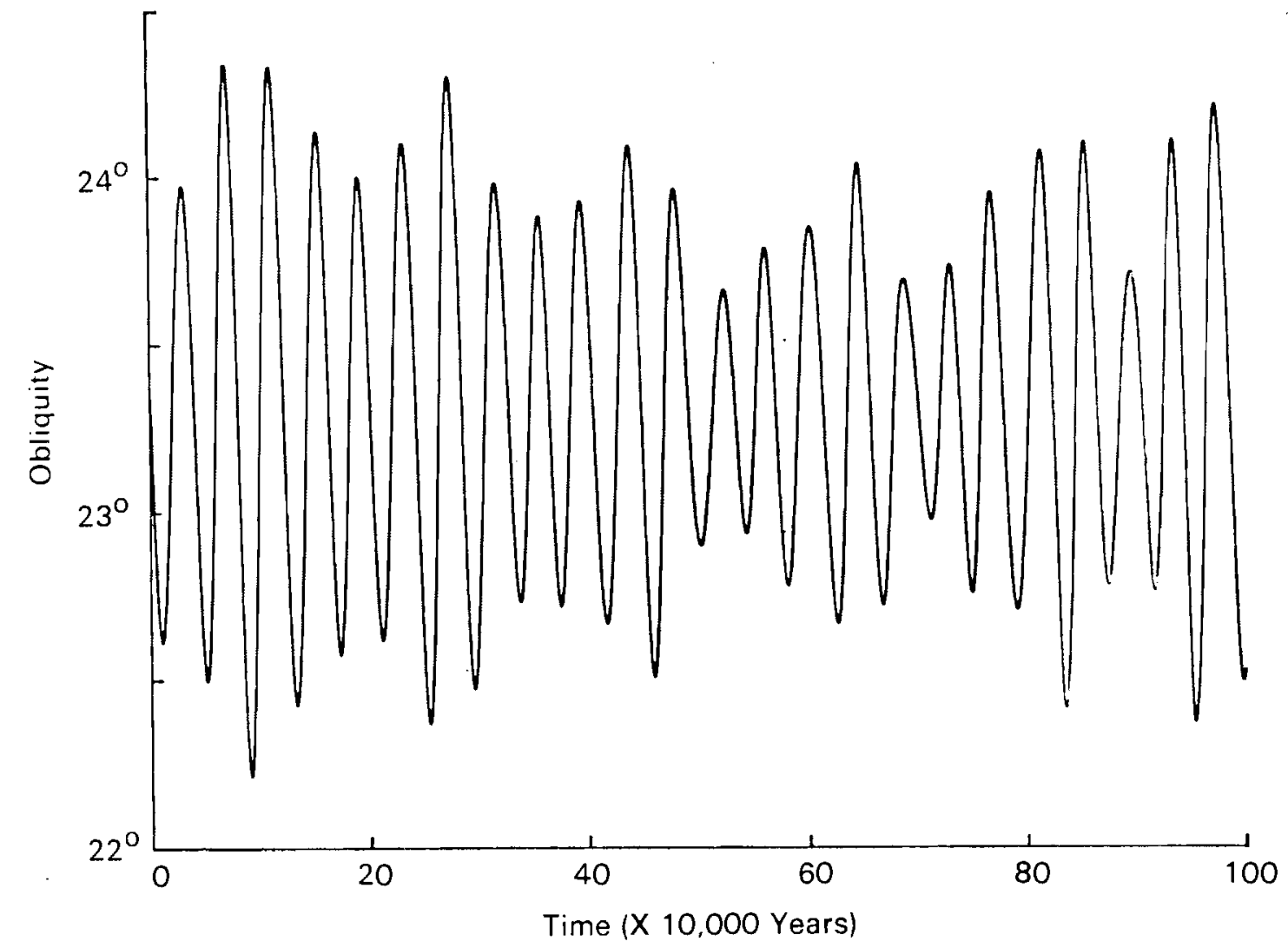

FIGURE 7. Predicted Values of 0bliquity of the Earth's Axis for the Next Million Years Based on the Solutions of Berger (1978).

The clearest corroborating evidence for the orbital forcing of the climate comes from oxygen-isotope analysis of ocean sediments. As an air mass travels from the equator over the oceans, water molecules that contain oxygen-16 are preferentially removed by evaporation relative to water molecules with oxygen-18. The oceans are slightly enriched in oxygen-18, and the snow that falls at high latitudes is enriched in oxygen-16. Thus, when an ice age begins, the continental ice sheets grow removing water from the ocean and the ocean water left behind thereby becomes enriched in the heavier oxygen-18. These changes in isotopic ratio can be determined from the skeletal remains of organisms in the deep sea sediments. It should be noted that the isotope record is also partially dependent on past temperatures. The isotopic composition of carbonate shells is known to be affected by the temperature of the water in which the shells formed. More oxygen-18 is incorporated into the shells when the oceans are cooler. Thus, a record of the changes in global 


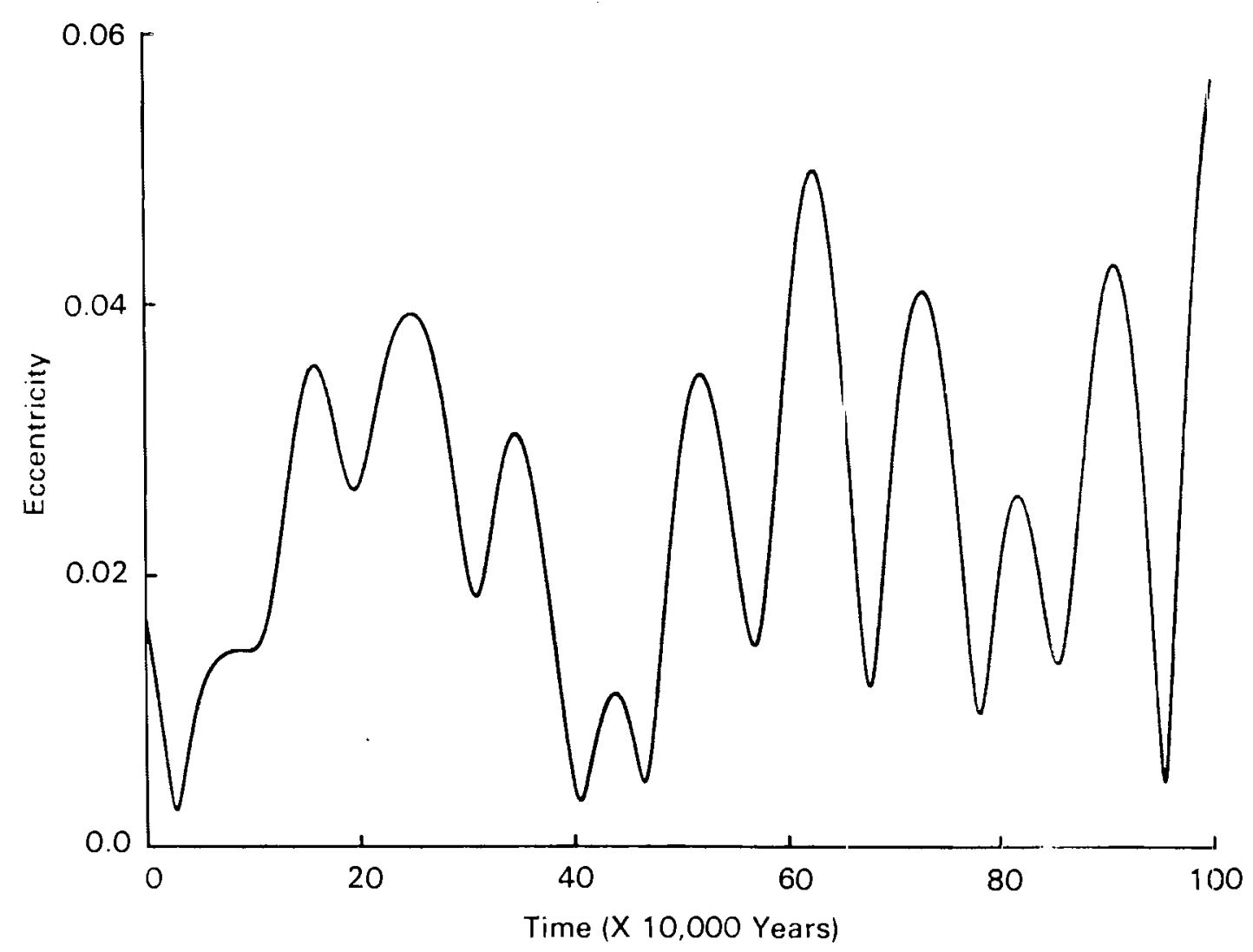

FIGURE 8. Predicted Values of Eccentricity of the Earth's Orbit for the Next Million Years Based on the Solutions of Berger (1978).

ocean temperatures and ice volume can be studied. Analysis of this isotope record suggests that a large proportion of climatic variability can be attributed to the Milankovitch effect (Hays et a1. 1976). Kuk1a (1978) has used these relatively well-known orbital parameters to clevelop an Astronomic Climate Index (ACLIN) to predict the gross climate states. When calibrated and tested against the radiometrically dated paleoclimatic evidence from the past 0.25 million years, the index suggests that the current interglacial climate will end within the next 10,000 years (Petrie et al. 1981).

If a glaciation occurs, the following changes should be considered:

1. A possible increase in precipitation together with a decrease in temperature would lead to a decrease in evaporation throughout the region of interest and would likely cause an increase in ground-water recharge. An increase in ground-water recharge could in turn affect 


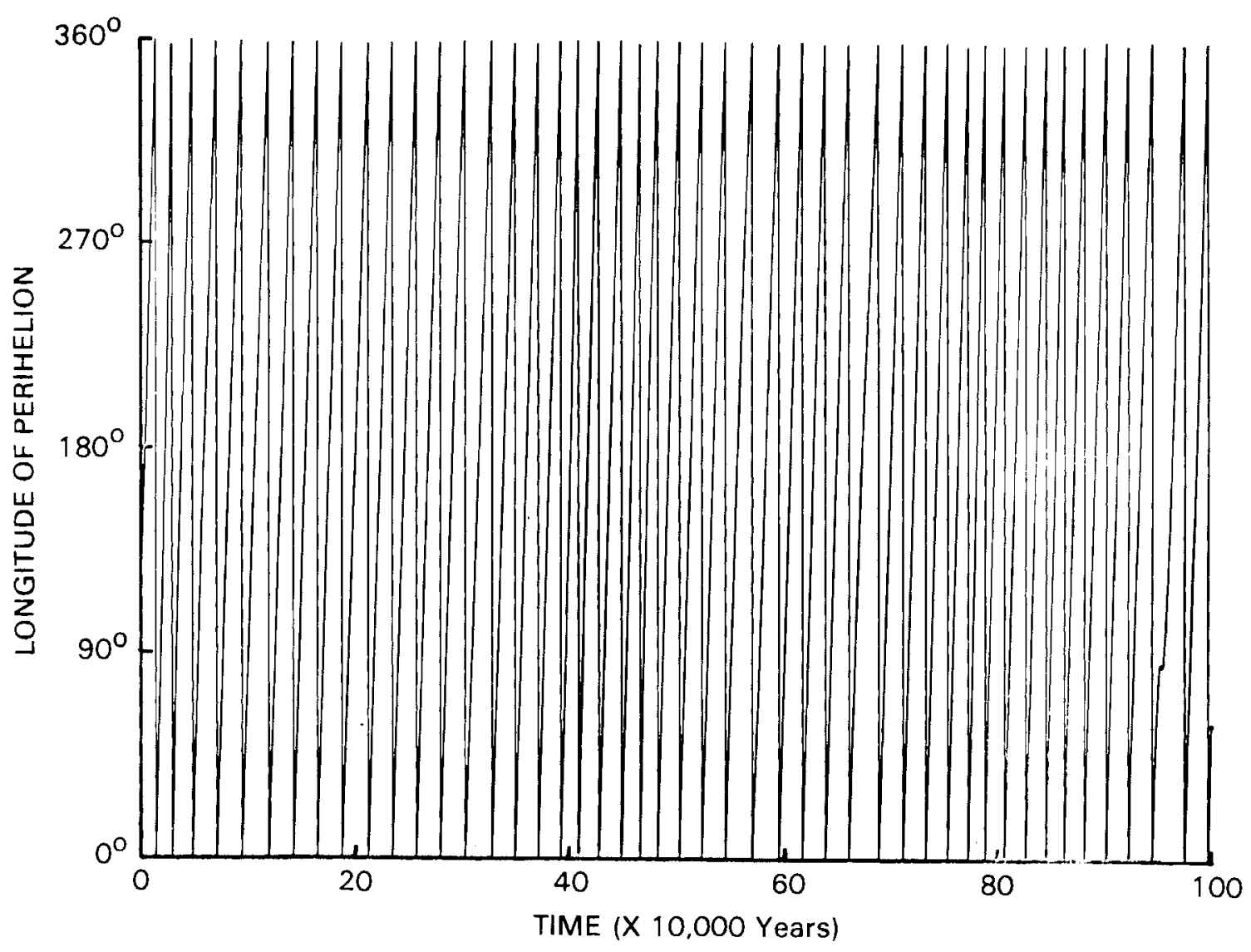

FIGURE 9. Predicted Values of the Longitude of Perihelion of the Earth's Orbit for the Next One Million Years Based on the Solutions of Berger (1978)

ground-water travel times as the ground-water system adjusted to this new boundary condition. A net change in runoff would also change the erosional and depositional characteristics of the rivers.

2. Lowered sea level would also contribute to a change in the erosional characteristics of rivers. This effect would be expected to be relatively small at both Texas and Utah sites because they are far from the sea.

Another major source of uncertainty is man's intervention. This is difficult to determine because it is possible to imagine a wide range of scenarios. However, with the burning of fossil fuels, man's significant effect on climate 
appears to be more than just speculation. The accompanying production of carbon dioxide gas seems to be functioning like a thermal blanket, causing a worldwide rise in average temperature (Smagorinsky et al. 1982). From a geologic perspective, consumption of the bulk of the world's known fossil fuel reserves quite likely would introduce a kind of 'super-interglacial' period. Moreover, the effect of the extra carbon dioxide would last for 1,000 years or more after the use of fossil fuels was discontinued, because the atmosphere would require that much time to rid itself of excess carbon dioxide (Imbrie and Imbrie 1979). In the resulting warm climate, the ice caps could melt substantially, significantly raising the sea level. Further, a study site may experience more evaporation with the increase in temperature. However, after the atmosphere rids itself of excess carbon dioxide, lang-term climate cycles may reassert themselves and a new ice age could occur (Figure 10). It is assumed that this possible super-interglacial would continue the trend of increasing aridity as the climate moves from a glacial to interglacial state. Thus, it is conservative to ignore this man-caused effect in the sense that less water would be available for recharge. 


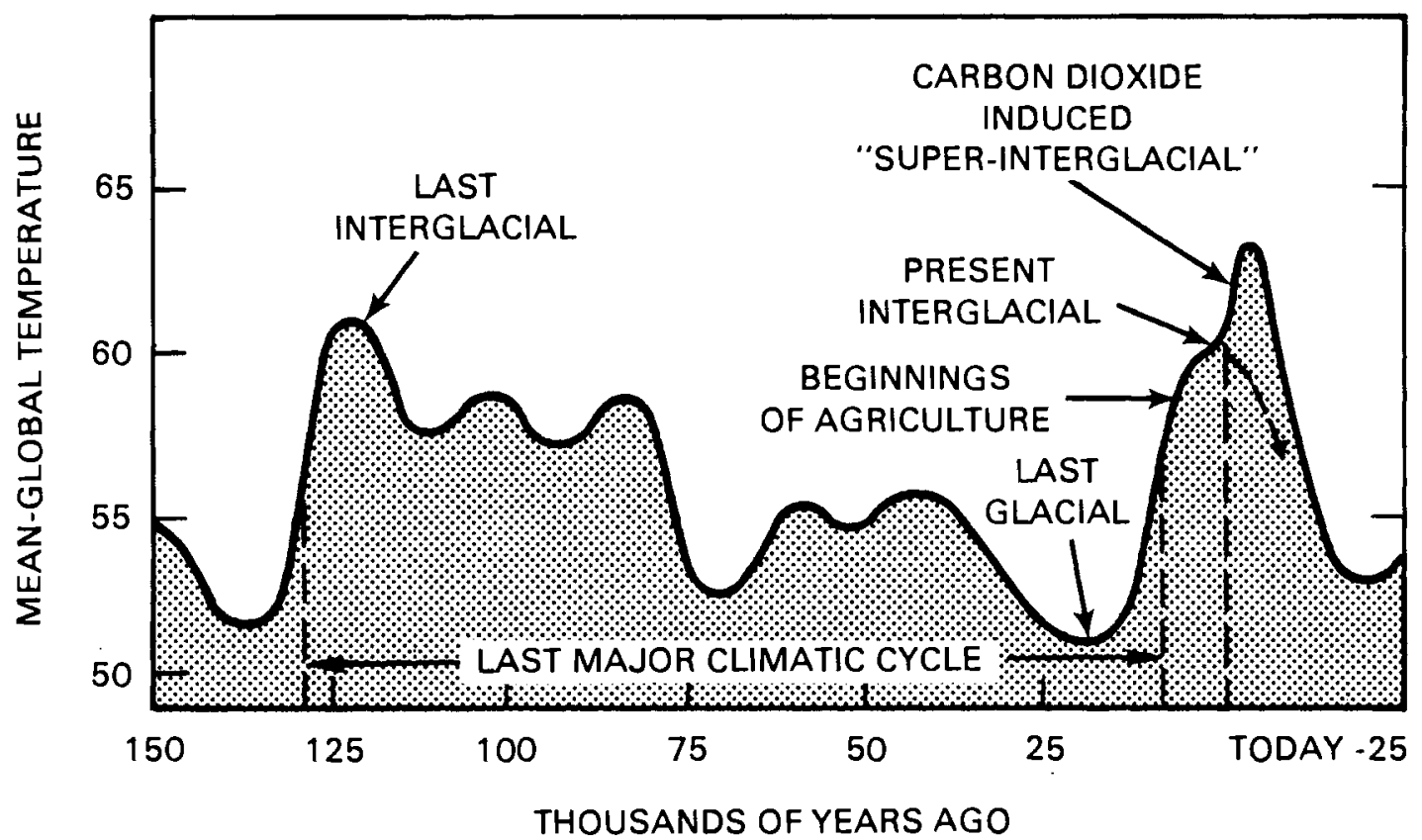

FIGURE 10. Climate Forecast for the Next 25,000 Years. According to the Milankovitch theory, the natural course of future climate (shown by the dashed line) would be a cooling trend leading to full glacial conditions 23,000 years from now. The warming effect of carbon dioxide, however, may induce a super-interglacial (modified from Imbrie and Imbrie 1979). 
The current climate of the Palo Duro Basin is semiarid and continental. It is transitional between the desert conditions on the west and the humid climates to the east and southeast. The climate is characterized by low and irregularly distributed precipitation, high evaporation, and marked daily and seasonal fluctuations in temperature. Records from the last 40 years (Figures 11 and 12) illustrate the large variation in precipitation. The yearly average ranges from 41 to $56 \mathrm{~cm}$ (Figure 13) acrosș the Texas panhandle. Most of the precipitation occurs as rain during the warm months from spring to fall. During these months warm, moist tropical air is carried into the area from the Gulf of Mexico. Intense, short-duration rainfall resulting from localized spring and summer thunderstorms is typical (Haragan 1976). The representative percentage frequency of thunderstorms in the region of the palo Duro Basin is given in Figure 14. An analysis of rainfall records from 25 stations (Figure 15) within a 22-county area (Table 3) showed significant concentrations of rainfall within 1 imited areas and locally pronounced precipitation gradients. Figure 16 shows a typical example of this locally intense rainfall. The seasonal fluctuations in temperature are illustrated in Figures 17 and 18. The annual average temperature ranges from $13^{\circ} \mathrm{C}$ to $16^{\circ} \mathrm{C}$ across the Panhandle (Figure 19).

High winds are characteristic of the study area. Prevailing winds are from the south at an annual average velocity of 12 to $15 \mathrm{mph}$. However, winds in excess of $30 \mathrm{mph}$ are common (Wendorf 1961). 


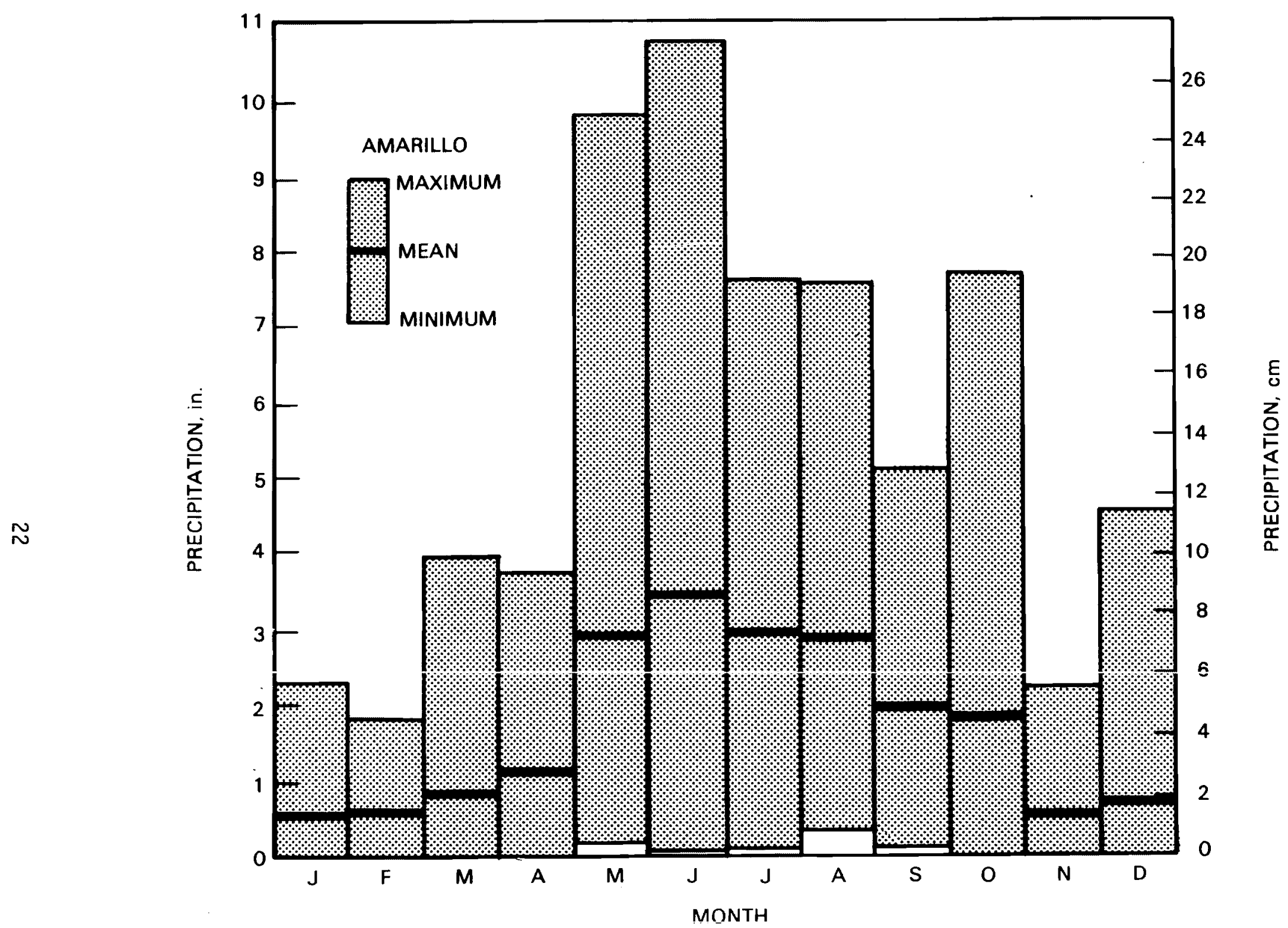

FIGURE 11. Range of Precipitation at Amarillo (Source: NOAA 1981) 


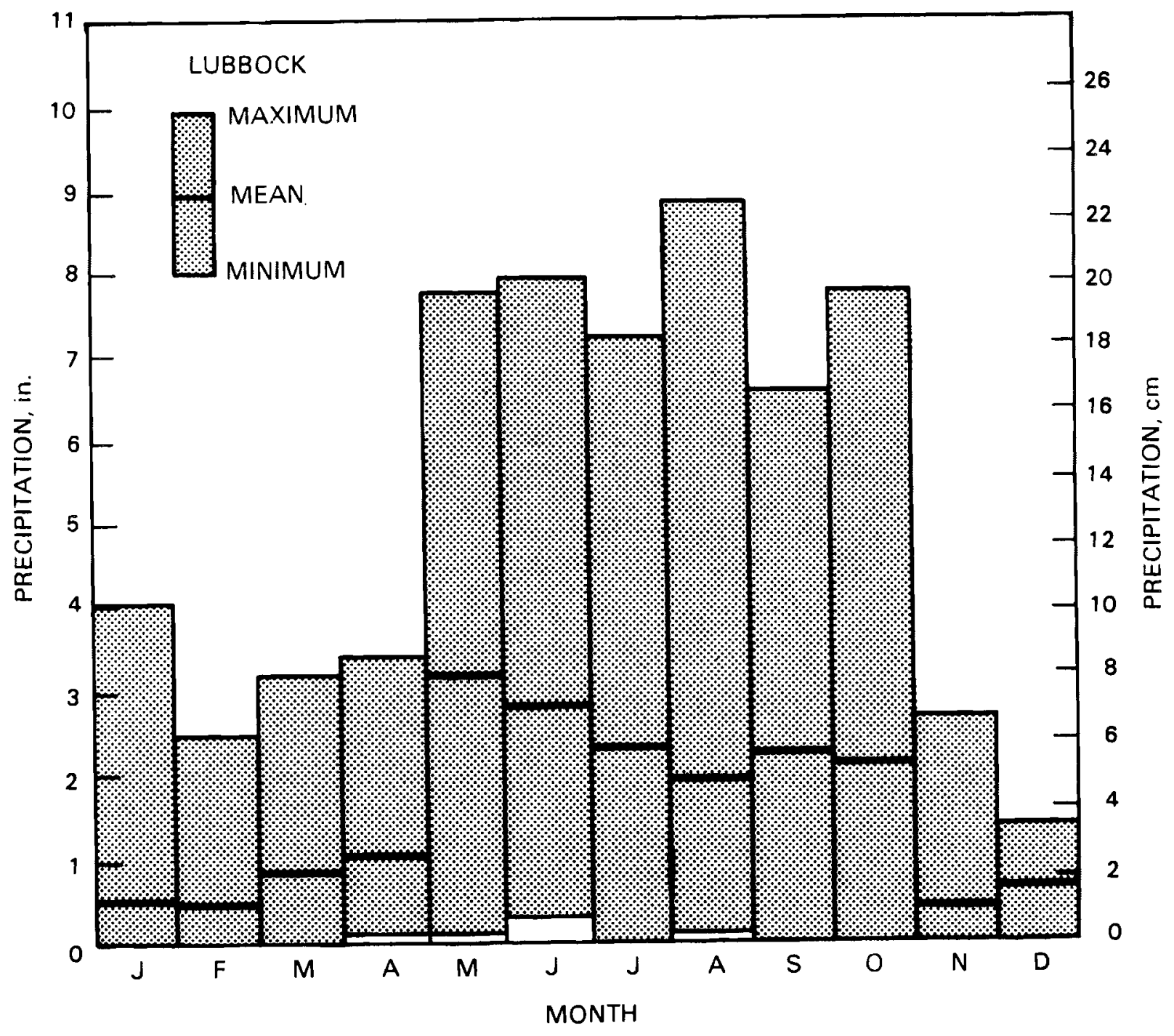

FIGURE 12. Range of Precipitation at Lubbock (Source: NOAA 1981). 


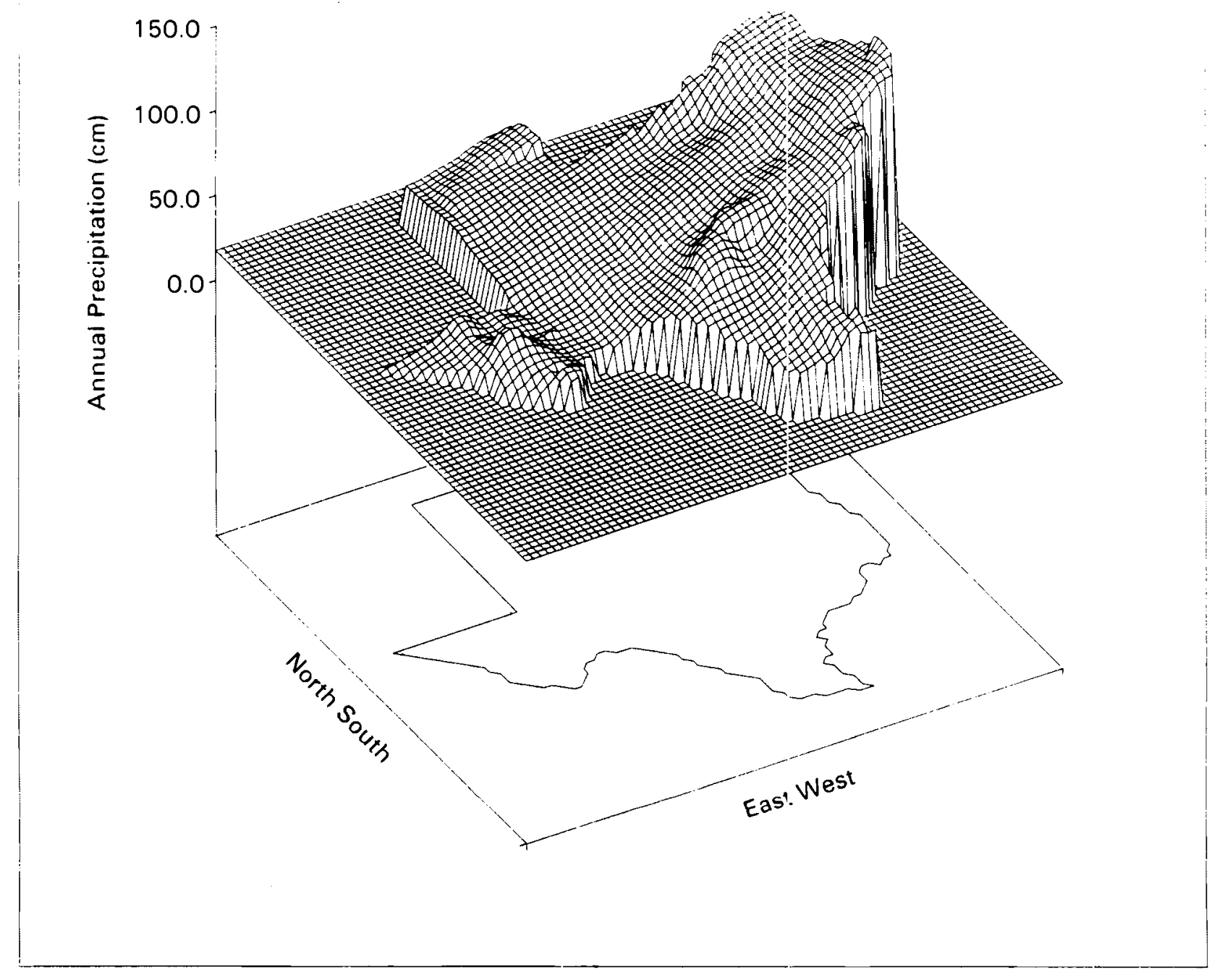

FIGURE 13. Average Annual Precipitation Across Texas (Raw data taken from NOAA 1974). 


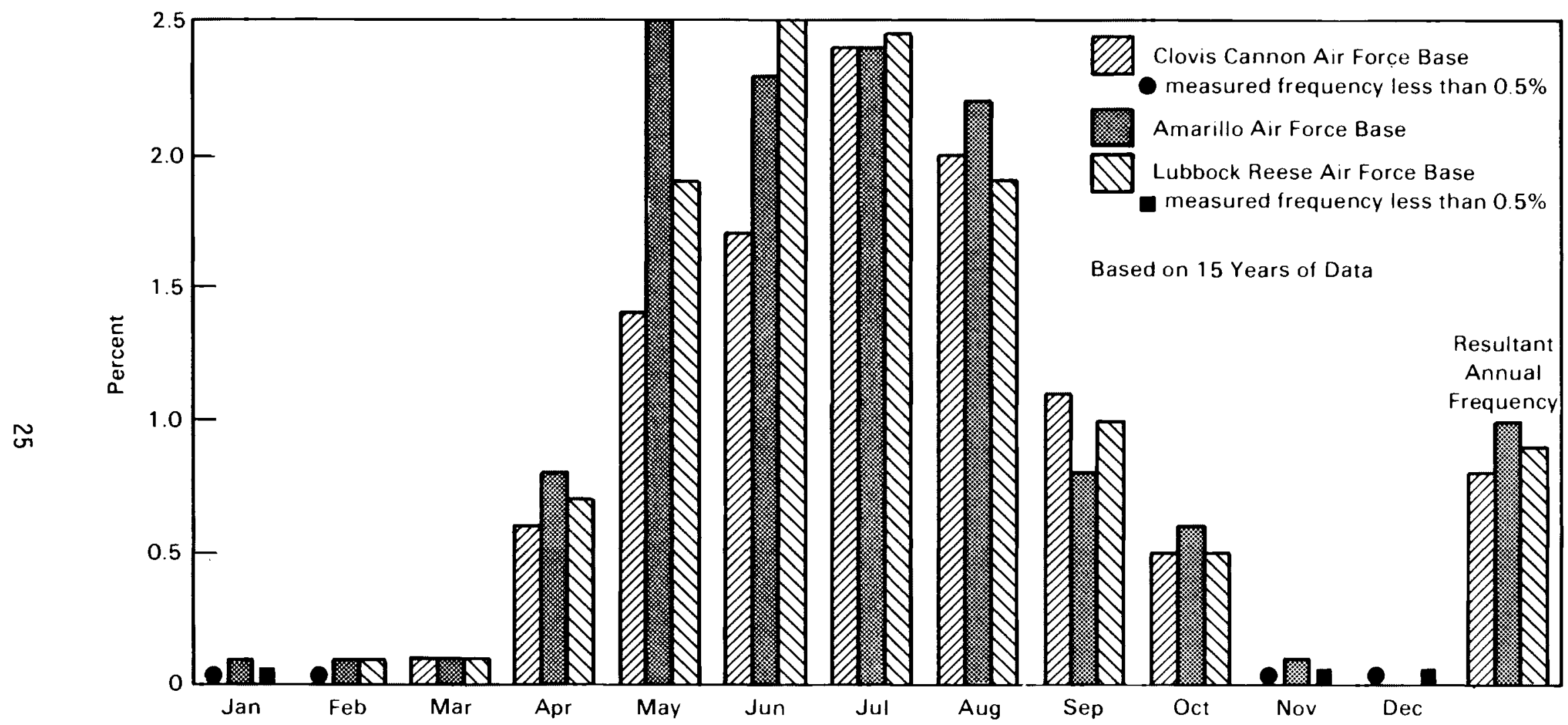

FIGURE 14. Percentage Frequency of Thunderstorms in the Region of the Palo Duro Basin, Based on Hourly Observations (Pei-lin Tien et al. 1983). 


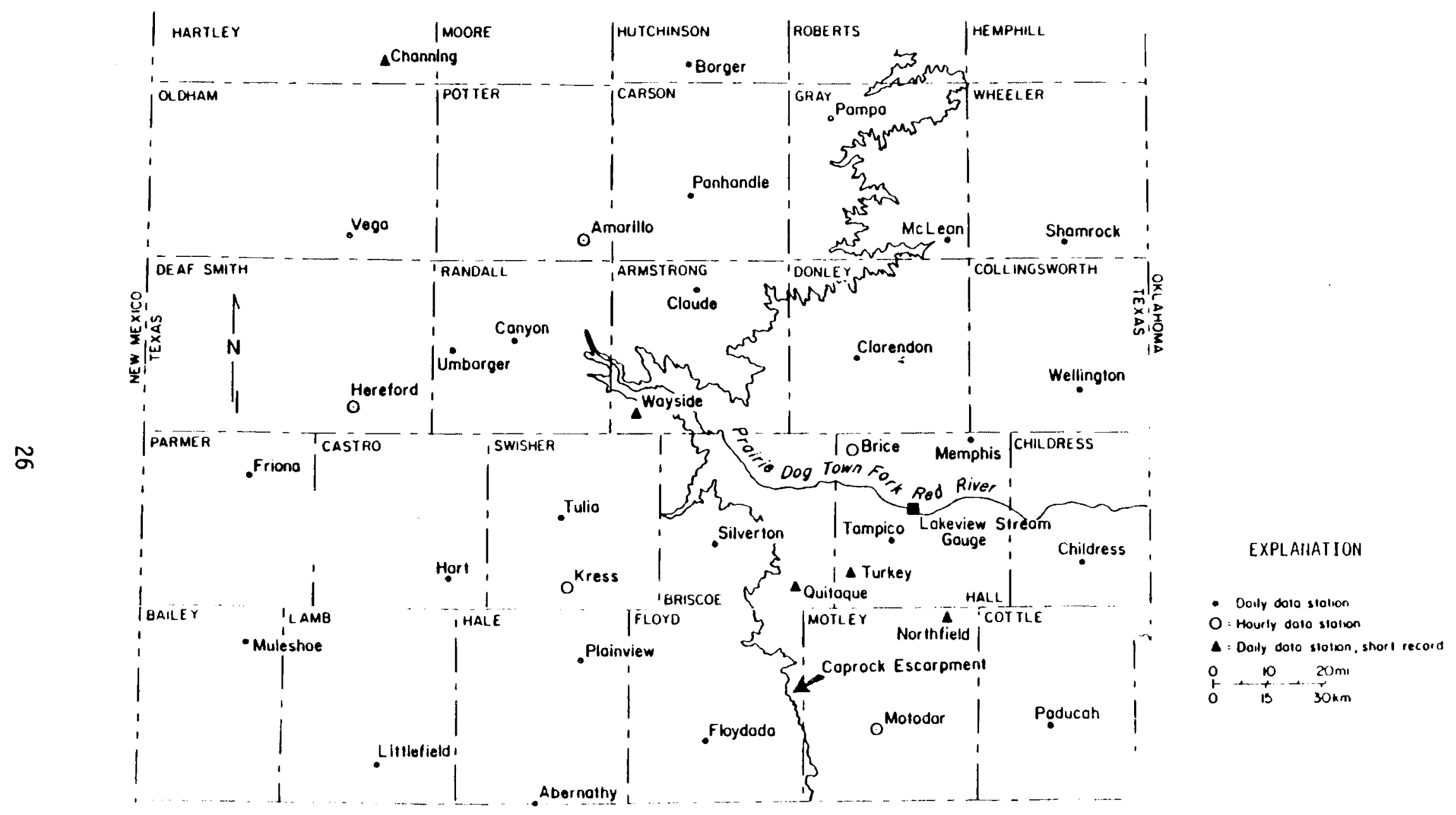

FIGURE 15. Rainfali Stations Within the Texas Panhandle Study Area (́Fintey and Gustavson 1980). Short-record stations have less than

15 years of data and/or records are incomplete and can be used only for analysis of selected storms. 
TABLE 3. Depth-Frequency Relationships for 24-hour Rainfall for Stations in the Texas Panhandle (Finley 1980)

\begin{tabular}{|c|c|c|c|c|c|c|c|}
\hline \multirow[b]{2}{*}{ Station } & \multirow{2}{*}{$\begin{array}{l}\text { Length of } \\
\text { Record, } \\
\text { yr }\end{array}$} & \multicolumn{6}{|c|}{ Total Rainfall, in.(a) } \\
\hline & & 2 & 5 & 10 & 25 & 50 & 100 \\
\hline Abernathy & 30 & 2.40 & 3.26 & 3.85 & 4.60 & 5.19 & 5.75 \\
\hline Amari110 & 29 & 2.49 & 3.40 & 4.04 & 4.79 & 5.39 & 6.02 \\
\hline Borger & 16 & 2.49 & 3.53 & 4.42 & 5.20 & 5.92 & 6.62 \\
\hline Canyon & 55 & 2.66 & 3.94 & 4.92 & 6.01 & 6.87 & 7.70 \\
\hline Childress & 26 & 2.53 & 3.18 & 3.72 & 4.35 & 4.86 & 5.36 \\
\hline $\mathrm{Cl}$ arendon & 60 & 2.91 & 4.07 & 4.93 & 5.92 & 6.75 & 7.50 \\
\hline Claude & 61 & 2.66 & 3.57 & 4.28 & 5.10 & 5.76 & 6.42 \\
\hline Floydada & 33 & 2.55 & 4.00 & 4.88 & 5.96 & 6.79 & 7.62 \\
\hline Friona & 42 & 2.23 & 2.96 & 3.48 & 4.14 & 4.66 & 5.18 \\
\hline Hart & 24 & 2.40 & 3.29 & 4.03 & 4.81 & 5.45 & 6.09 \\
\hline Hereford & 44 & 2.55 & 3.48 & 4.21 & 5.06 & 5.74 & 6.40 \\
\hline Littlefield & 46 & 2.55 & 3.41 & 4.05 & 4.83 & 5.42 & 6.01 \\
\hline Matador & 29 & 2.58 & 3.36 & 3.94 & 4.59 & 5.12 & 5.64 \\
\hline Mcclean & 17 & 3.00 & 3.74 & 4.27 & 4.90 & 5.44 & 5.97 \\
\hline Muleshoe & 56 & 2.30 & 3.08 & 3.63 & 4.31 & 4.85 & 5.37 \\
\hline Paducah & 26 & 2.78 & 4.02 & 4.87 & 5.92 & 6.71 & 7.51 \\
\hline Pampa & 33 & 2.55 & 3.55 & 4.30 & 5.15 & $5.84^{\circ}$ & 6.51 \\
\hline Panhandle & 50 & 2.58 & 3.70 & 4.65 & 5.64 & 6.44 & 7.22 \\
\hline Plainview & 63 & 2.53 & 3.35 & 4.02 & 4.79 & 5.41 & 6.01 \\
\hline Shamrock & 47 & 2.81 & 3.76 & 4.67 & 5.56 & 6.26 & 6.96 \\
\hline Silverton & 29 & 2.49 & 3.48 & 4.20 & 5.04 & 5.73 & 6.40 \\
\hline Tampico & 29 & 2.62 & 3.68 & 4.52 & 5.42 & 6.18 & 6.87 \\
\hline Tulia & 28 & 2.04 & 3.07 & 3.82 & 4.69 & 5.37 & 6.05 \\
\hline Vega & 54 & 2.27 & 3.13 & 3.71 & 4.43 & 4.97 & 5.56 \\
\hline Wellington & 31 & 2.75 & 3.83 & 4.63 & 5.51 & 6.23 & 6.92 \\
\hline Mean: & & 2.55 & 3.51 & 4.25 & 5.07 & 5.73 & 6.39 \\
\hline Standard & & & & & & & \\
\hline Deviation: & & 0.21 & 0.31 & 0.42 & 0.54 & 0.64 & 0.73 \\
\hline
\end{tabular}

(a) 1 inch $=25.4 \mathrm{~mm}$ 


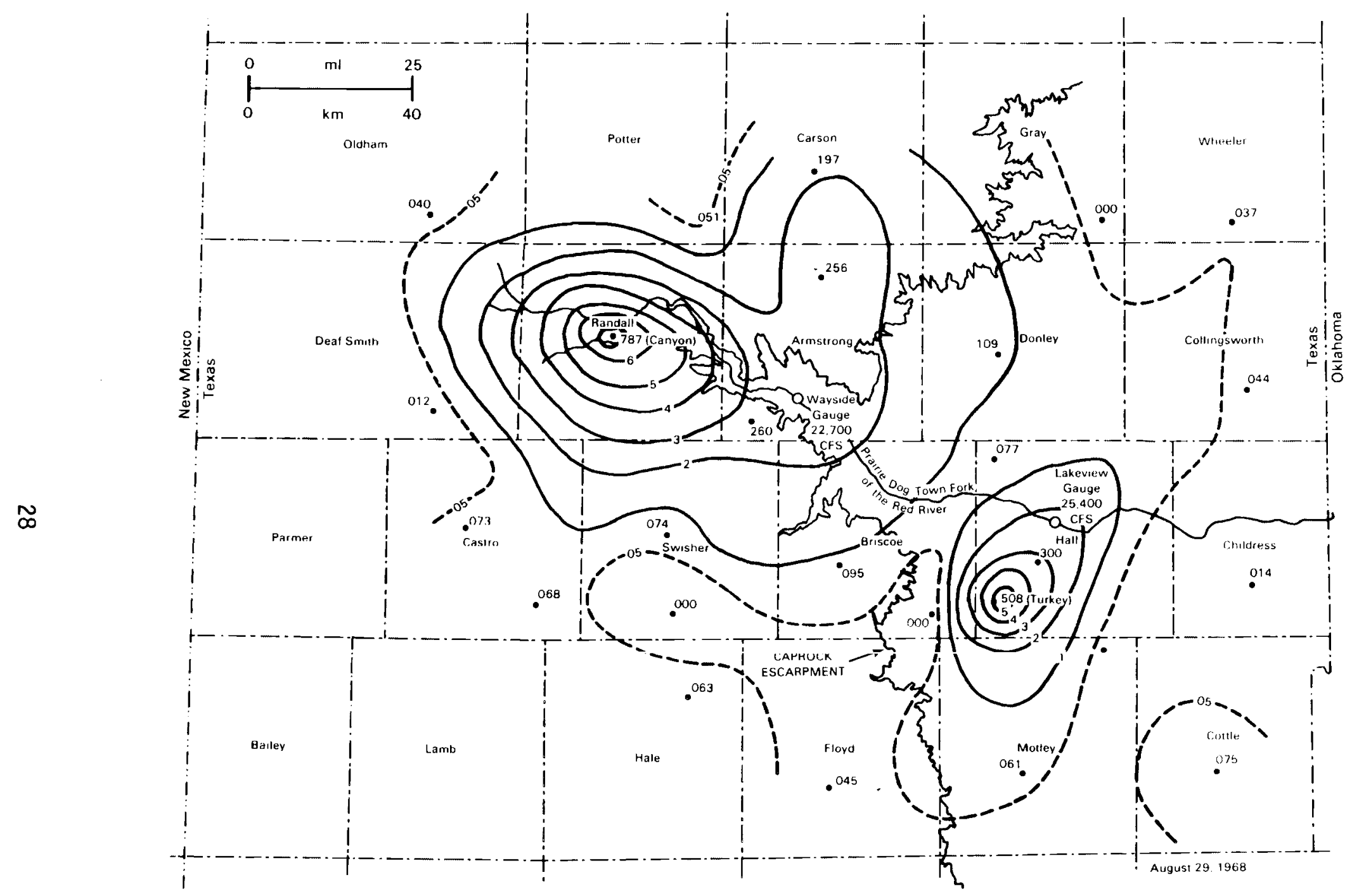

FIGURE 16. Isohyetal Map (contours in inches) Based on 24-hour Rainfall Ending 7 a.m., August 29, 1968 (Finley 1979). 


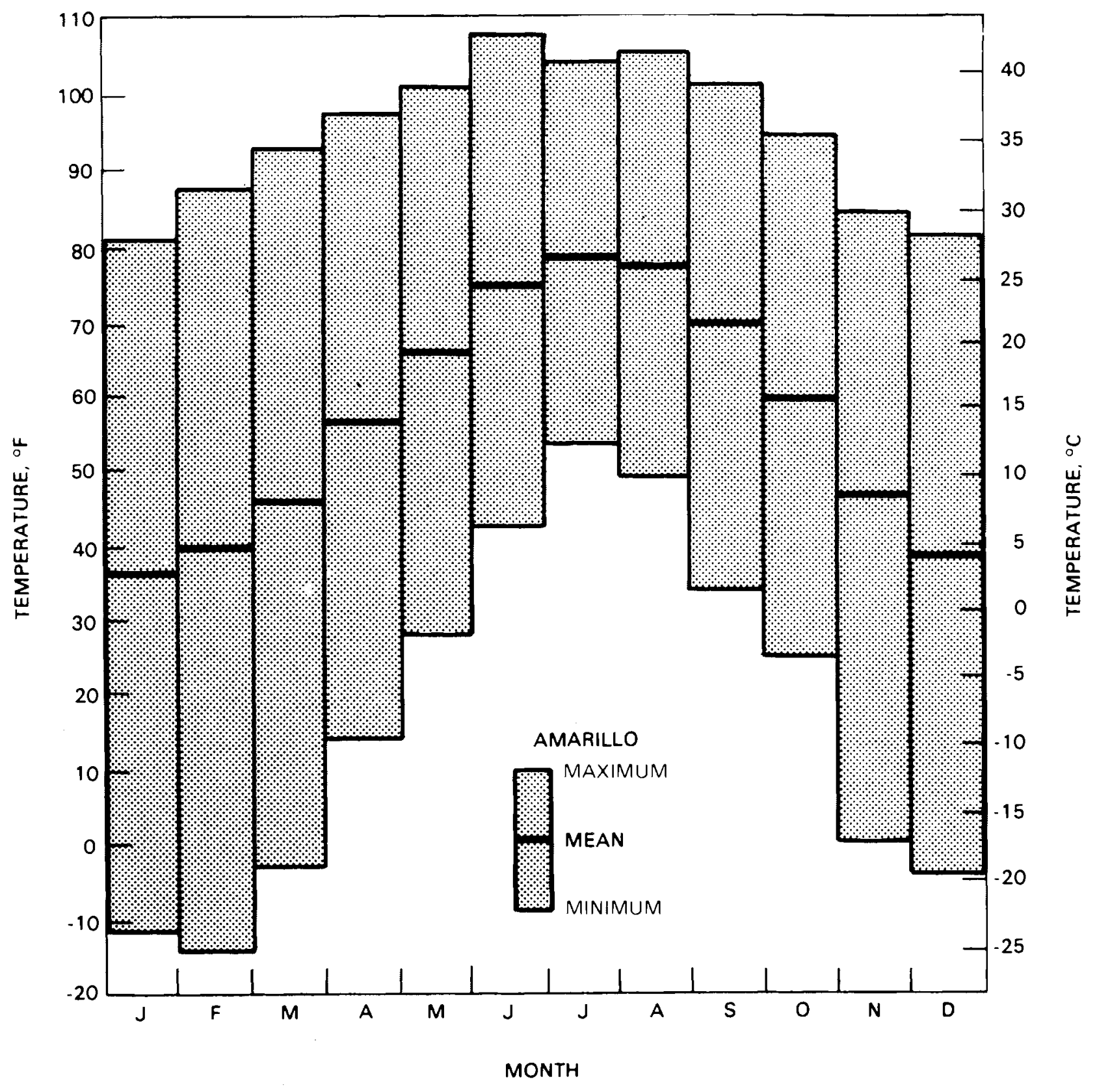

FIGURE 17. Range of Temperature at Amarillo (Source: NOAA 1981). 




FIGURE 18. Range of Temperature at Lubbock (Source: NOAA 1981). 


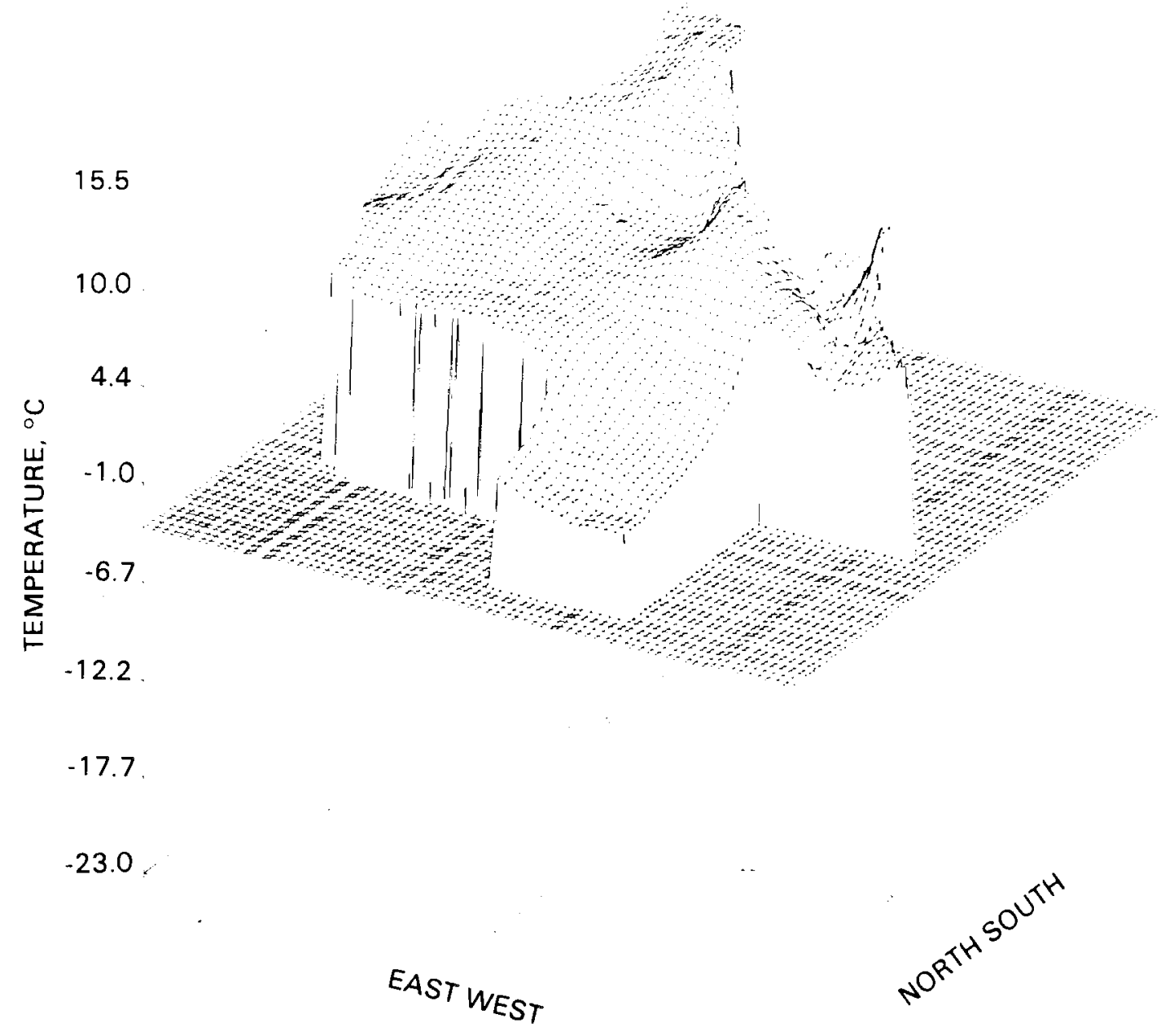

FIGURE 19. Annual Temperature Across Texas (raw data taken from NOAA 1974). 


\section{POSSIBLE FUTURE CLIMATE CONDITIONS AT THE PALO DURO BASIN}

Our previous argument suggests a reasonable probability that the climate will return to a glacial ice age within the time of interest. Accepting this premise, the following section summarizes ideas about the nature of climate during the last full glacial period in the Palo Duro Basin area.

An important consideration is temperature. Several lines of evidence suggest that, at least in the region of the study area, summer temperatures were colder on the order of $10^{\circ} \mathrm{C}$ during a full glacial (Leopold 1951; Antevs 1954; Reeves 1965, 1973, 1976; Wendorf 1961; Wendorf and Hester 1975). One quantitative measurement of temperature change is provided by changes in timberlines. The upper timberlines 1 ie close to the $10^{\circ} \mathrm{C}$ isotherm for the warmest month on middle-latitude mountains (Griggs 1946; Daubenmire 1954; Wardle 1965). Hence, by using the location of paleotimberlines and the correct temperature-lapse rate, paleosummer temperatures can be estimated. Paleobotanic evidence, particularly pollen and pack rat middens, and paleosnowlines also provide insight on paleotemperatures. There does not seem to be complete concensus on the change in winter temperatures during glacial periods. For instance, Lanner and Van Devender (1981) speculate that winter temperatures may have been milder due to a reduced frequency of incursion by arctic air masses. Wendorf and Hester (1975) also found fossil evidence that suggests winters "seemingly were mild and possibly no colder than at present." However, given that 1 ) it is conservative to assume a lower temperature (e.g., less evaporation promoting more recharge), and 2) most of the precipitation falls (at this time) in the summer (Figures 11 and 12), it will be assumed in this study that temperatures could be lowered $10^{\circ} \mathrm{C}$ throughout the year.

The degree to which precipitation changed during a full glaciation is a subject of discussion in the literature. Considerable evidence from many parts of the world (Frenzel 1973; Fairbridge 1970; Grove 1968; Galloway 1970, 1983; Leopold 1951) as well as simulations with global circulation models (Williams et al. 1974; Williams 1975) indicate, in general, that the climate was not only cooler but significantly drier during the last glacial period in mid-latitude regions. This idea is in keeping with the fact that the study area currently 
receives nearly all its moisture from the Gulf of Mexico. Spaulding et al. (1983) suggest that there is a strong theoretical basis for a full-glacial reduction of summer precipitation, relative to that: of today. Summer rainfall depends on the development of a strong Burmuda high (Bryson and Lawry 1955; Van Devender and Wiseman 1977; Hales 1974). Circulation around this system causes a flow of oceanic air from the Gulf of Mexico northwest to the arid West, with resultant proportions of summer rainfall declining with distance from the Gulf (Hastings and Turner 1965). Global cooling would have weakened such subtropical high-pressure systems and the increased latitudinal gradient would have restricted their influence to more southerly latitudes. Hastings and Turner (1965) further point out that the frequency of warm-season precipitation in the deserts depends on local high temperatures and convective uplift, and fewer convective thunderstorms would occur if summer temperatures were lower. However, Reeves (1976) states "incontrovertible evidence shows that the last full glacial climate on the Southern High Plains was pluvial in the classical sense [i.e., increased precipitation], only becoming dry during the waning stages." Moreover, Van Devender (1977) and others suggest that winter precipitation in the Southwest increased as the growth of continental glaciers shifted storms tracks south. Reeves (1973) offers as one piece of evidence, a water budget done for smal1, closed-lake basins that existed during the last pluvial in west Texas. This study suggested that precipitation was approximately double todays value. In reconciling these differences, Reeves (1973) points out that "the seasonal and mean climates probably varied as much during glacial times as they do now between west Texas and southern Arizona" and thus having increased precipitation in one part of the Southwest is not necessarily inconsistent: with having decreased precipitation in another part of the world. 


\section{ANALYSIS OF CLIMATE FOR THE PALO DURO BASIN}

If precipitation doubles, then recharge might increase roughly about the same order of magnitude. However, precise quantitative estimates are difficult to obtain. For instance, the pattern of precipitation (e.g., seasonal distribution, frequency, and/or intensity) can affect the fraction of precipitation available for recharge, and it is extremely difficult to determine what this was, or will be, during glacial times. Further, Hafsten (1961) and others find evidence that during a glacial maximum, trees replaced grassland or desert scrub over at least part of the Llano Estacado. Such a change in vegetation would also change both the runoff and evapotranspiration of the system.

While there is a need for further work (see Conclusions), before any future recharge and its effects on a possible repository can be estimated, several considerations suggest this recharge may not turn out to be a serious problem for a potential repository. These considerations are listed below.

1. A new glacial age may not occur during the 10,000-year time period of interest. For instance, some workers in the field (e.g., Emiliani 1972; Morner 1972) suggest that a new glacial ice age will not occur until after the 10,000-year time frame. In part, this represents a difference between how one defines the start of a new glacial ice age; however, a major reason for differences in estimating the start of a new glacial ice age is an incomplete understanding of the nature of the underlying driving forces.

2. Another reason for believing increased recharge would not present a serious threat, is the inherent low permeability of the salt where the repository will be located. For example, modeling results indicate that a doubling of the recharge would not significantly affect a deep repository.

3. As mentioned above, recharge is not just a simple linear function of rainfall, but also a function of other factors such as new vegetation. However, in the case of the Palo Duro region the expected change in vegetation would tend to promote an increase in evapotranspiration (Table 4). In other words, the biosphere may adjust to take advantage of the new water, rather than let it pass into the ground. 
Tien et al. (1983) make an argument that under the current climate the palo Duro region may produce nearly the maximum sediment yield. Maximum sediment yield from a drainage basin requires 10 to $14 \mathrm{in}$. (25 to $36 \mathrm{~cm})$ of effective precipitation per year at a mean annual temperature of $50^{\circ} \mathrm{F}\left(10^{\circ} \mathrm{C}\right)$ (Langbein and Schumm 1958). In the Texas Panhandle the mean annual temperature is $50^{\circ} \mathrm{F}\left[10^{\circ} \mathrm{C}\right.$ at Lubbock and $\left.57.4^{\circ} \mathrm{F}\left(14.1^{\circ} \mathrm{C}\right)\right]$ at Ararillo. Evapotranspiration causes the effective precipitation within the Palo Duro Basin to be less than $20 \mathrm{in}$. $(50.8 \mathrm{~cm})$ of measured annual precipitation. Ten-year, average-streamflow data at the Lakeview gauging station on the Prairie Dog Town Fork of the Red River indicate a $0.52 \mathrm{in} .(1.32 \mathrm{~cm})$ annual runoff (Dougherty 1979). This runoff indicates that the Rolling plains receives an annual effective precipitation of $17 \mathrm{in.}(43.2 \mathrm{~cm})$ (Finley and Gustavson 1980). Using the LangbeinSchumm curve (Figure 20) with this combination of mean annual temperature and effective precipitation, we see that the Palo Duro Basin may be producing nearly the maximum sediment yield now. Thus, a return to glacial times may not herald a major increase in water-driven erosion.

Further, the fact that many small lakes (Wendorf and Hester 1975) (Figure 4) developed during the past glaciation suggests that integrated stream drainage will remain poorly developed, if and when full glaciation occurs. 
TABLE 4. Estimated Evapotranspiration for Types of Vegetation in the Western United States (Todd 1972)

Vegetation Type

\footnotetext{
Forest:

Lodgepole pine

Engelmann spruce-fir

White pine-1arch-fir

Mixed conifer

True fir

Aspen

Pacific Douglas-fir-hemlock-redwood

Interior ponderosa pine

Interior Douglas-fir

Chaparral and woodland:

Southern California chaparral

Cal ifornia woodland-grass

Arizona chaparral

Pinon-juniper

Semiarid grass and shrub

Alpine
}

\begin{tabular}{c} 
Annual \\
Evapotranspiration, in. $(\mathrm{cm})$ \\
\hline
\end{tabular}

$19(48.3)$

$15(38.0)$

$22(55.9)$

$22(55.9)$

$24(61.0)$

$23(58.4)$

$30(76.2)$

$17(43.2)$

$21(53.3)$

$20(50.8)$

$18(45.7)$

$17.5(39.4)$

$14.5(36.8)$

$10.6(26.9)$

$20(50.8)$ 


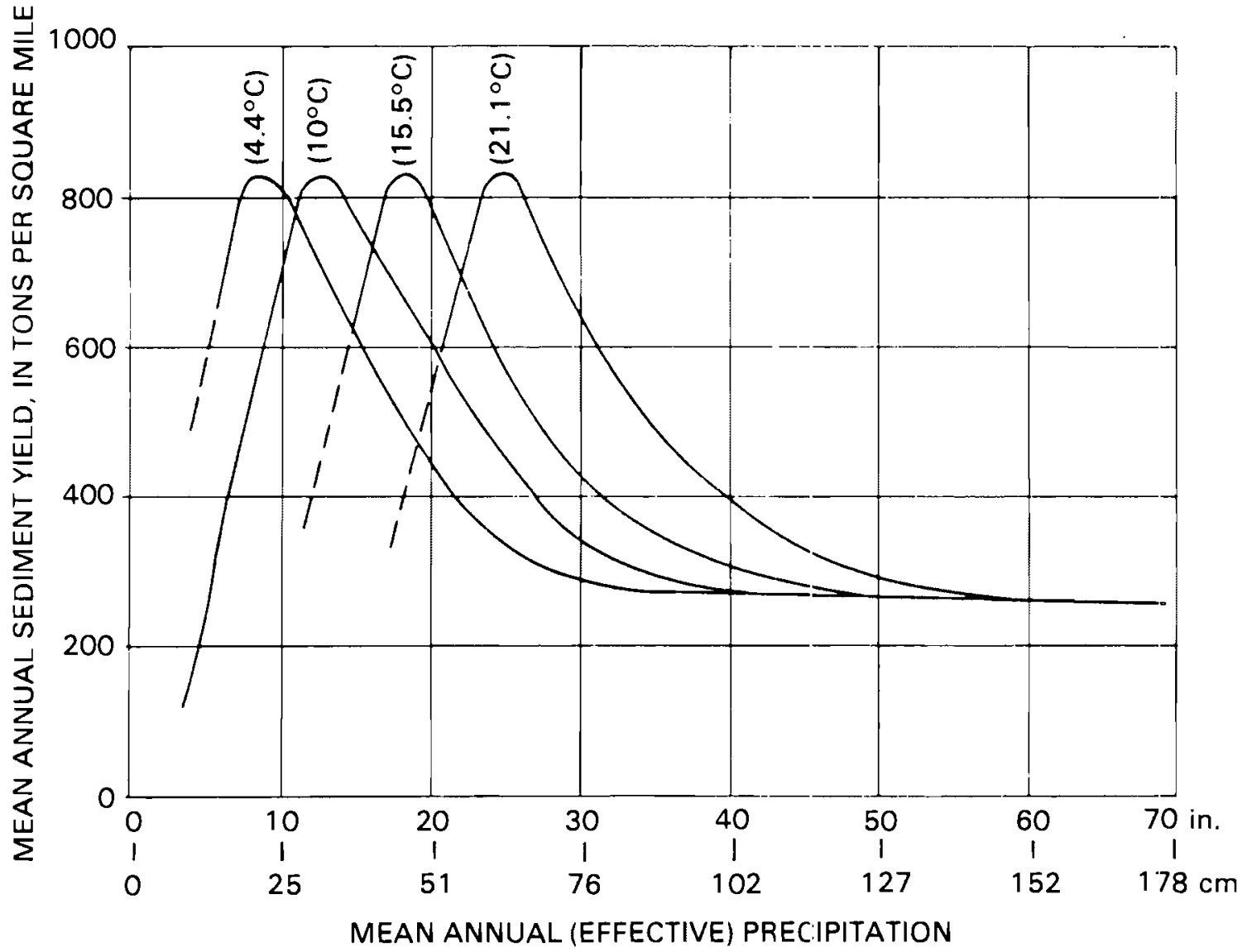

FIGURE 20. Curves Depicting the Relationship Between Mean Annual Sediment Yield and Mean Annual Precipitation at Various Mean Annual Temperatures $\left({ }^{\circ} \mathrm{C}\right)$ (modified from Schumn ). 


\section{CURRENT CLIMATE AND METEOROLOGY CONDITIONS AT THE GIBSON DOME}

The climate of this mid-latitude steppe area is predominantly cool and semiarid with isolated areas classified as mid-latitude desert (Bechtel National 1982a). Terrain is rugged, characterized by deep valleys and high mountains, with height variations on the order of $100 \mathrm{~m}$. These terrain factors and a general sparseness of climatic data make a detailed climatic description of the area difficult. However, colder temperatures and higher precipitation generally occur with higher terrain.

Utah's climate is determined by its distance from the equator, its height above mean sea level, the location in the state with respect to the seasonal storm paths over the Intermountain region, and its distance from the principal moisture sources--the Pacific Ocean, the Gulf of California, and the Gulf of Mexico. The mountain ranges of the western United States have a marked influence on the state's winter climate. Before reaching Utah, Pacific storms from the northwest must first cross the sierras or the Cascades. As the moist air is forced to rise over these high mountains, a large portion of the moisture in the air masses falls as precipitation before the air mass reaches the site. Also, the normal track of winter storms is north of the Gibson Dome area, so winter precipitation is relatively low in the area. Summer precipitation is characterized by intense, localized thunderstorms caused by convection over the intensely heated desert areas and and by orographic uplift over mountainous areas.

No climatic data are available for the study area proper. The information used in this report was taken from Moab, a site outside but close to the study area. There, the average annual mean temperature is $12.7^{\circ} \mathrm{C}\left(54.8^{\circ} \mathrm{F}\right)$. July is the warmest month with temperatures ranging from $16.4^{\circ} \mathrm{C}\left(61.6^{\circ} \mathrm{F}\right)$ to $36.1^{\circ} \mathrm{C}$ $\left(97.0^{\circ} \mathrm{F}\right)$ and an average of $26.2^{\circ} \mathrm{C}\left(79.2^{\circ} \mathrm{F}\right)$. January is the coldest month with a range of $-8.17^{\circ} \mathrm{C}\left(17.3^{\circ} \mathrm{F}\right)$ to $5.4^{\circ} \mathrm{C}\left(41.7^{\circ} \mathrm{F}\right)$ and an average of $-1.4^{\circ} \mathrm{C}\left(29.4^{\circ} \mathrm{F}\right)$ (Figure 21). The average annual rainfall at Moab is $22.58 \mathrm{~cm}$ (8.89 in.). Monthly and seasonal variation in rainfall is sma11. October is the wettest month of the year and June is the driest (Figure 22). Snowfall, which occurs from October through May, averages $31.5 \mathrm{~cm}$ (12.4 in.) annually. 


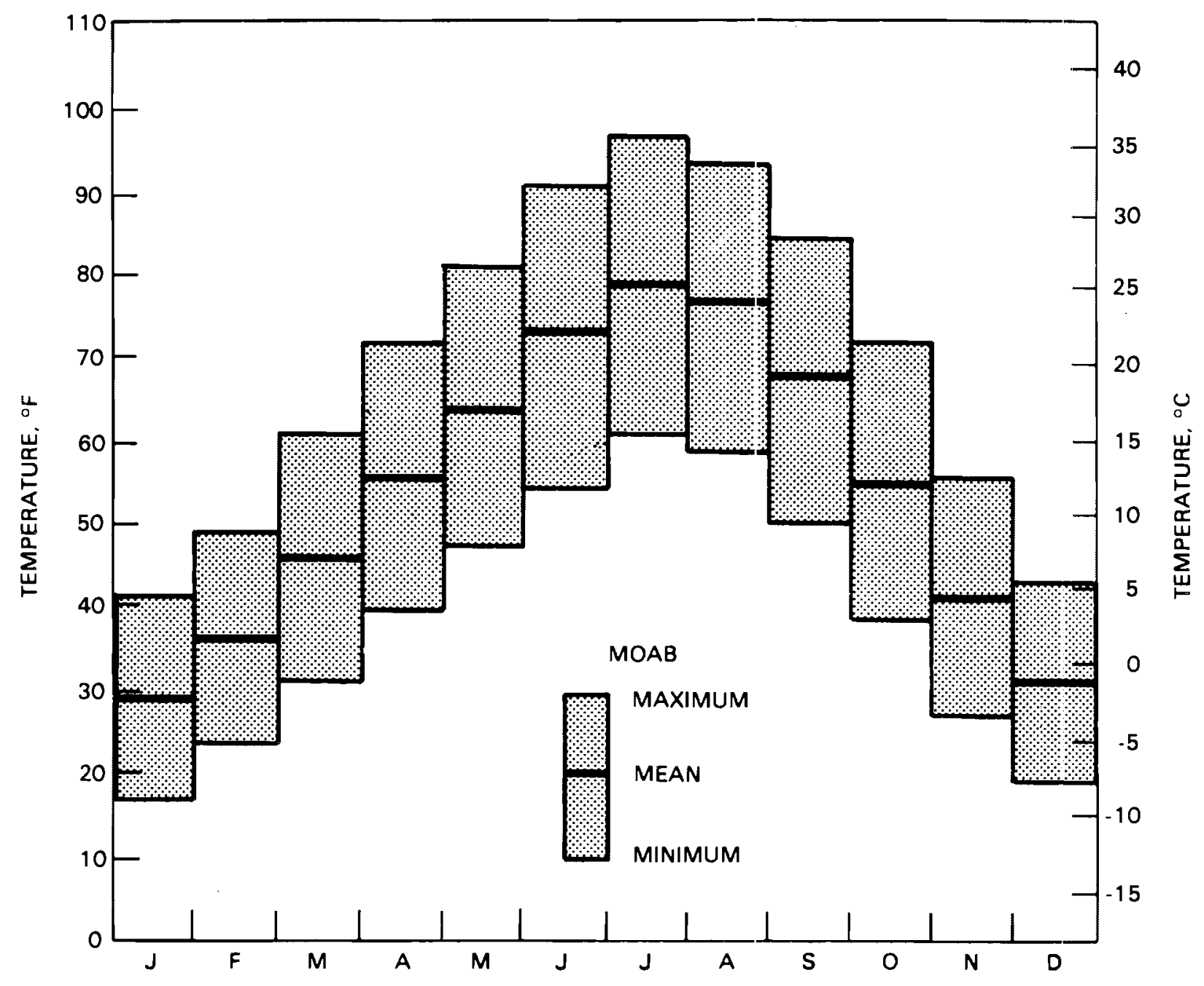

MONTH

FIGURE 21. Range of Temperature at Moab, Utah (Source: DNWI-144, Bechtel National 1982a).

Figure 23 shows the direction and average wind speed for the town of Green River. Green River is outside the study area, approximately $70 \mathrm{miles}$ northwest of the site. It is the only available source for wind data within the site vicinity. The average annual wind speed at Green $2 i v e r$ is $4.7 \mathrm{mph}(2.1 \mathrm{~m} / \mathrm{s})$, and the prevailing directions are from the southwest through west. The highest annual average wind speed of $6.7 \mathrm{mph}(3.0 \mathrm{~m} / \mathrm{s})$ was from the south-southwest. 


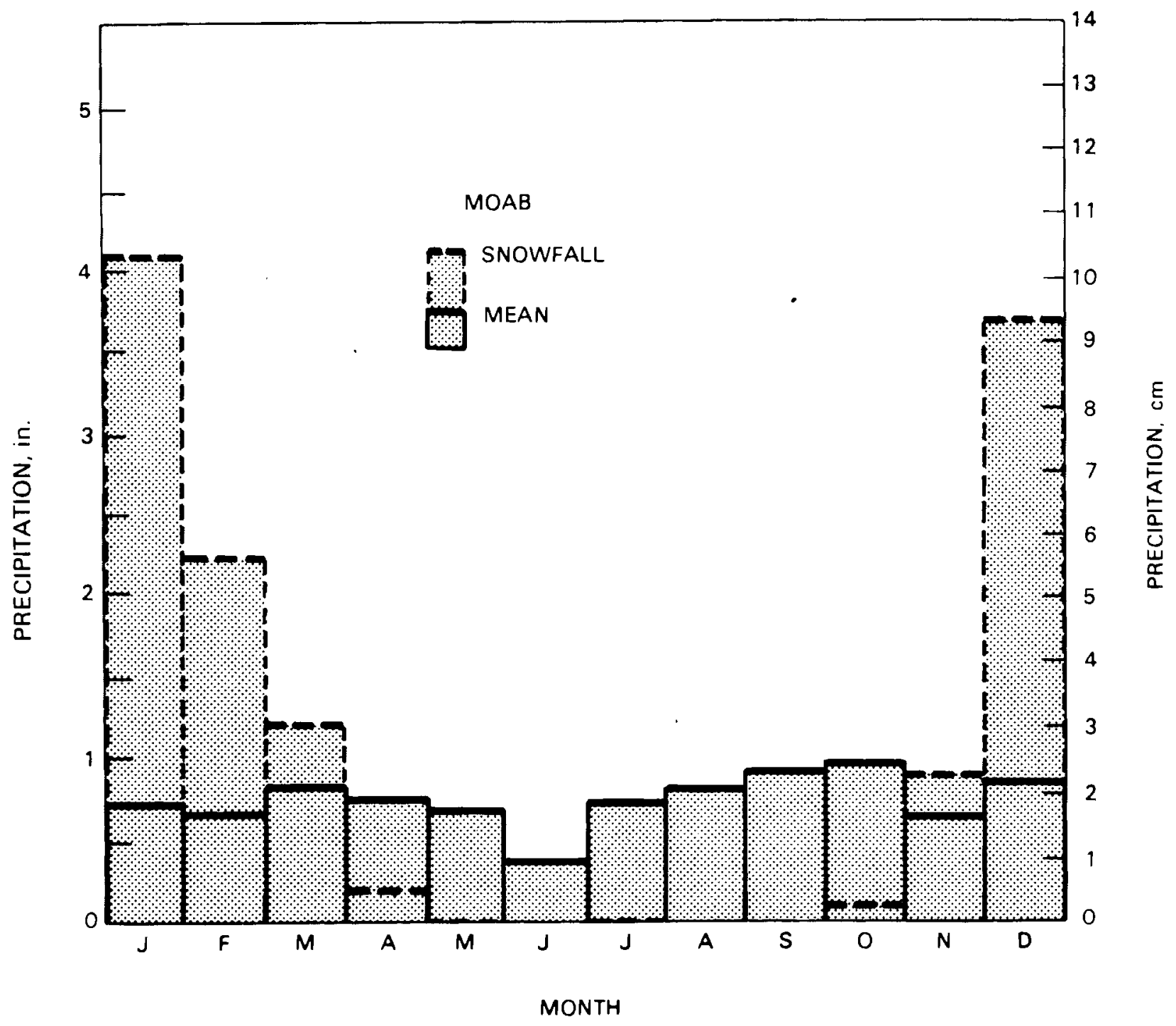

FIGURE 22. Range of Precipitation at Moab, Utah (Source: ONWI-144, Bechtel National 1982a).

About $17 \%$ of the time the winds are calm. Both wind speed and direction may differ between Green River and the study area because of variations in local terrain and the channeling effects of canyons. 


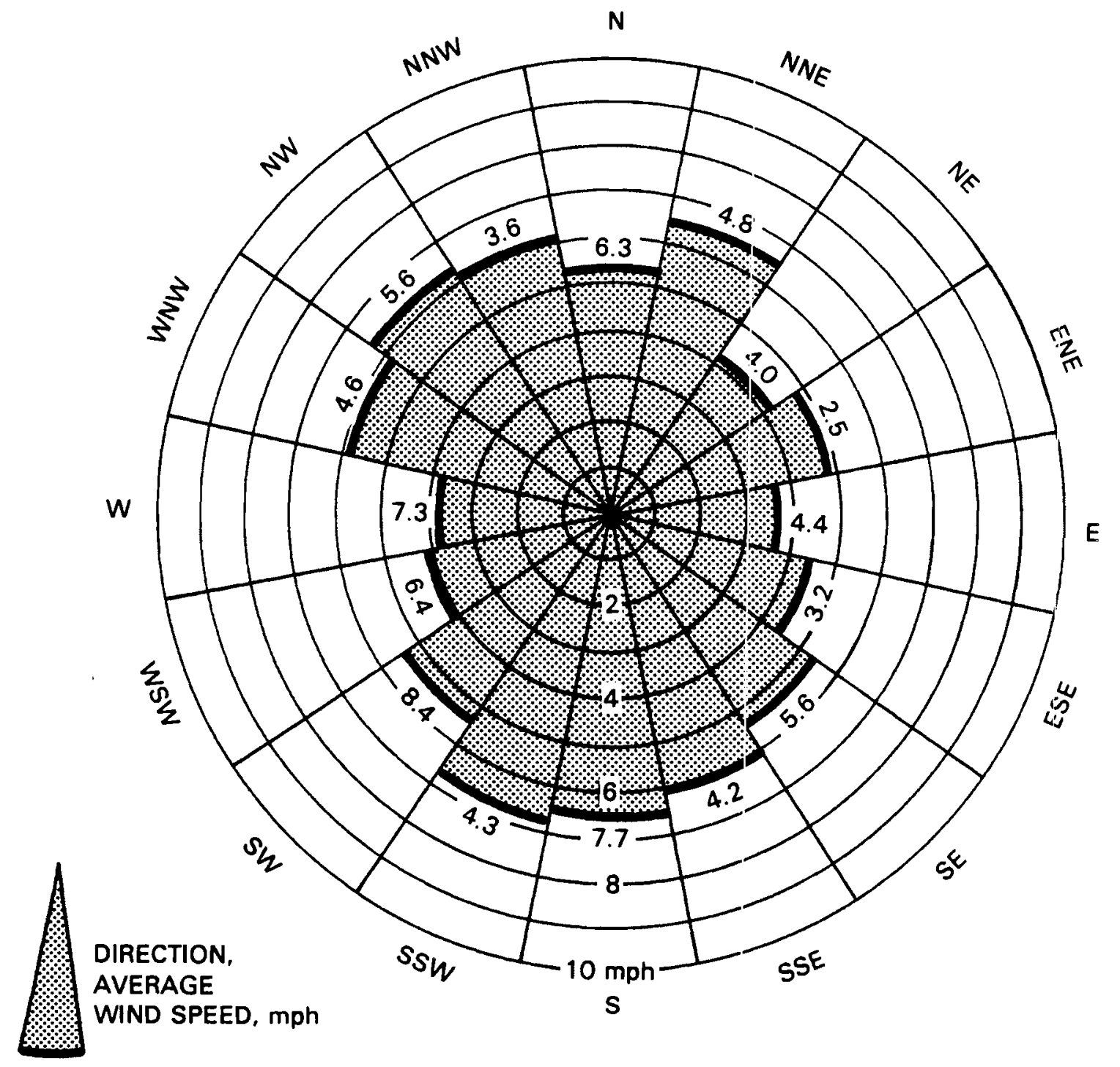

\subsection{FREQUENCY, \%}

FIGURE 23. Annual Wind Means for Green River (Source: ONWI-144, Bechtel National 1982a). 


\section{POSSIBLE FUTURE CLIMATE CONDITIONS AT THE GIBSON DOME}

Our previous argument suggests the probability that the climate may return to a glacial ice age within the time of interest. Accepting this premise, the following section summarizes the current ideas as to the nature of the climate during the last full glacier period in the study area.

Estimates of temperatures during a glacial maximum in the Southwest range from approximately $2^{\circ}$ to $10^{\circ} \mathrm{C}$ cooler than present temperatures (Spaulding, Leopold and Van Devender 1983; Galloway 1983) (Table 5). This assessment is based on 1) evidence of lowered timberlines, 2) interpretation of climatic tolerances of fossil vegetation and pollen found in pack rat middens, and 3) indications of paleosnowline elevations. Data collected to date from pack rat middens in the Paradox Basin suggest that during the last 13,000 to 14,000 years, temperatures were no lower than $5^{\circ} \mathrm{C}$ below present. However, because these data do not extend back to the time of glacial maximum, temperatures during maximum glacial advance are conservatively assumed to be $10^{\circ} \mathrm{C} l o w e r$ than today.

The degree to which precipitation changed during a full glaciation is also a subject of controversy (Table 5). Significantly increased precipitation in the American west has long been the interpretation presented to explain the presence of extensive lakes that formed in the Great Basin during a glacial period. However, considerable evidence from many parts of the world (e.g., Frenzel 1973; Fairbridge 1970; Grove 1968; Galloway 1983) as well as evidence from global circulation models (Williams et al. 1974; Williams 1975) indicate that the climate was not only cooler, but significantly drier during the last glacial era in the middle latitudes. This idea is consistent with the theory that evaporation from the oceans decreased (as a result of lower temperatures associated with a full glacial climate and changes in atmospheric circulation patterns). Recent analyses suggest that a net gain of greater effective moisture during glaciation may be attributed to increased cloud cover, cooler temperatures, and an increase in winter precipitation. The annual precipitation 
TABLE 5. Paleoclimatic Reconstruction for the Full Glacial of the American Southwest (modified from Spaulding, Leopold and Van Devender 1983)

\begin{tabular}{|c|c|c|c|c|c|c|c|c|}
\hline Reference & Data Base & Location & $\wedge \mathrm{T}_{\mathrm{a}}$ & $\Delta \mathrm{T}_{\mathbf{s}}$ & $\Delta T_{W}$ & $\Delta P$ & & qp \\
\hline Antevs 1952 & Hydrologic budgets & Lake Lahontan, Nevada & $-? .5$ to -3.0 & -- & -- & +8 to +16 & $50 \mathrm{t}$ & to 100 \\
\hline Broecker and $0 r r 1958$ & Hydrologic budgets & Lake Lahontan, Nevada & -5 & - & $\cdots$ & +20 & & 80 \\
\hline Snyder and Langbein 1962 & Hydrologic budgets & Lake Spring, Nevada & $-5(a)$ & $-7.2^{(b)}$ & - & +20 & & 67 \\
\hline Mifflin and wheat 1979 & Hydrologic budgets & Nevada, statewide & -2.8 & -- & -- & +8.4 to -24 & & $68^{(c)}$ \\
\hline Antevs 1954 & Relict snowlines & North-central New Mexico & - & -5.6 & -- & +23 & & -- \\
\hline Leopold 1951 & $\begin{array}{l}\text { Hydrologic budgets and } \\
\text { snowl ine changes }\end{array}$ & Lake Estancia, New Mexico & -6.6 & -9 & -2.8 & +18 to +25 & 50 & to 70 \\
\hline Galloway 1970 & $\begin{array}{l}\text { Solifluction } \\
\text { deposits }\end{array}$ & $\begin{array}{l}\text { Sacramento Mountains, } \\
\text { New Mexico }\end{array}$ & -10.5 & -10 & -- & -4.6 & & - \\
\hline Bachhuber and McClellan 1977 & $\begin{array}{l}\text { Foraminifera } \\
\text { distributions }\end{array}$ & Lake Estancia, New Mexico & - & -9.7 & - & -- & & -- \\
\hline Brackenridge 1978 & $\begin{array}{l}\text { Relict cirques and } \\
\text { cryogenic deposits }\end{array}$ & $\begin{array}{l}\text { Montana to Arizona } \\
\text { (lat. } 45^{\circ} 40^{\prime} \mathrm{N} \text { to } 33^{\circ} 20^{\prime} \mathrm{N}\end{array}$ & $-7(d)$ & -- & -- & 0 & & 0 \\
\hline Reeves 1966 & Hydrologic budgets & $\begin{array}{l}\text { Llano Estacado, } \\
\text { western Texas }\end{array}$ & -5 & -8 & -- & +39 & & 89 \\
\hline
\end{tabular}

NOTE: $\Delta \mathrm{T}_{\mathrm{a}}, \Delta \mathrm{T}_{S}$, and $\Delta \mathrm{T}_{\mathrm{w}}$ are changes in ${ }^{\circ} \mathrm{C}$ in annual, summer, and winter temperatures, respectively. $A P$ is change in annual precipitation in $\mathrm{cm}$; $\% \mathrm{P}$ is $A P$ /modern $P$

(a) Extrapolated by Morrison (1965), Schumm (1965), and Mifflin and Wheat (1979).

(b) Extrapolated by Schumm (1965) and Brackenridge (1978).

(c) Statewide average.

(d) Minimum est imate. 
may have increased only slightly because summer precipitation decreased comparably (Spaulding, Leopold and Van Devender 1983). Plant fossils found in pack rat middens that postdate the full glacial maximum have been interpreted to indicate that annual precipitation 11,000 to 13,000 years ago may have exceeded the present day values by as much as 60 to $120 \%$ in southeast Utah, depending on the lapse rate used in the calculation (Betancourt and Biggar 1984). Although the lower value is more consistent with data collected elsewhere in the Southwest, the higher value would provide a more conservative approach for estimating the effects of increased precipitation on ground-water recharge at Davis Canyon. 
. 
ANALYSIS FOR THE GIBSON DOME AREA

If precipitation increases by $120 \%$, then recharge might increase roughly or about the same order of magnitude. However, like the Palo Duro location, precise quantitative estimates are difficult to acquire. For instance, the pattern of precipitation can affect the fraction of precipitation available for recharge, and it is extremely difficult to determine what this was, or will be, during glacier times. Further, as discussed earlier, a fair amount of evidence exists showing that woodland plants moved into what are now arid and semiarid regions of much of the Southwest during glacier times. Such a change in vegetation would also change both the runoff and evapotranspiration of the system.

While there is a clear need for further work (see Conclusions) before future recharge and its effects on a possible repository can be estimated, note that many of the same considerations found at the Palo Duro site also appear to apply to this site and suggest that a change in recharge may not be a serious problem for a potential repository. These considerations (page 35) include the fact that 1) a new glacier age may not occur during the time of interest, 2) the salt where the repository may be located has an inherent low permeability, and 3) other factors, such as changes in vegetation, may mitigate any changes at a deep repository caused by changes in recharge.

Glacial and periglacial processes have directly affected only areas higher than the potential repository locations. Therefore, the potential repository locations in the study area have not been glaciated, nor is it likely that glaciers will override the area during the lifetime of the repository (wCC 1982). However, glacial and periglacial activity in the headwaters of drainages have been manifested downstream. Stream incision in the Paradox Basin has been episodic during the Quarternary. Periods of deposition, rather than incision, have occurred as evidenced by the remnants of coarse- and finegrained terraces adjacent to incised streams and gravel on pediment surfaces. Little bedrock incision appears to have occurred during the last 8,000 to 10,000 years, supporting the concept that bedrock incision in the Paradox Basin is cyclic and may occur primarily during periods of higher stream discharge 
coincident with glacial cycles. Holocene deposits are fine-grained and commonly consist of multiple channel fills (WCC 1982). During historic time, arroyos up to several tens of feet deep formed in the Holocene deposits throughout southeastern Utah and other areas in the Southwest. Overgrazing or climatic change were initially given as causes of this phenomena. However, the evidence of earlier similar events in Holocene deposits suggests that the formation gully is just one stage of a long-term pattern of cyclic alluviation and trenching.

Maximum long-term (including several full-glac;al climatic events) incision rates have been calculated for the Green River and Colorado canyons using paleomagnetically reversed alluvial deposits. In the vicinity of the Paradox Basin these rates range from $15 \mathrm{~cm}(0.5 \mathrm{ft})$ to $55 \mathrm{~cm}(1.8 \mathrm{ft})$ of erosion per 1000 years (Bigger, Hardan and Gillan 1981; WCC 198:). It can be seen that even these rates will not cause direct disruption 0 : a deep repository. 
The climate in the study area is temperate (Figures 24 and 25) with warm, humid summers and mild winters. Warm, moist, tropical air from the Gulf of Mexico predominates over the area, but in winter this air is frequently, though briefly, displaced by the intrusion of cold, polar, continental air. Thunderstorms and tornadoes occur in the area during all months of the year, but spring is the most likely time for these occurrences. Heavy thundershowers or severe weather are usually associated with cold storms or squall lines in advance of these storms.

Precipitation is nearly uniform over the year with fall being the driest season (Figure 26 and 27). Excessive amounts of rain may occur in any season, however, precipitation in summer and fall is usually associated with tropical depressions moving inland from the gulf. 


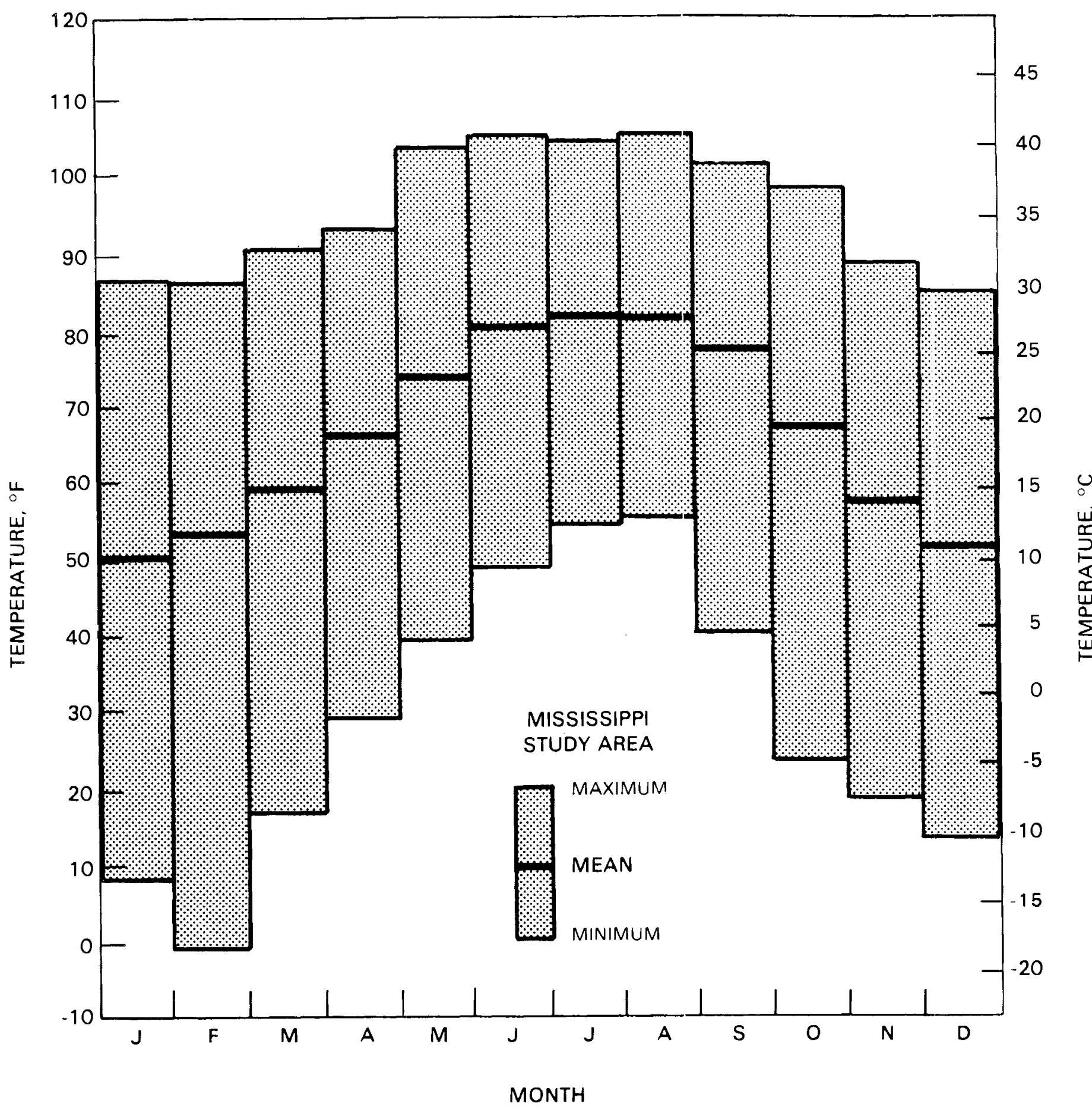

FIGURE 24. Range of Temperature Near Richton Dome, Mississippi (Source: ONWI-193, Bechtel National 1982b). 


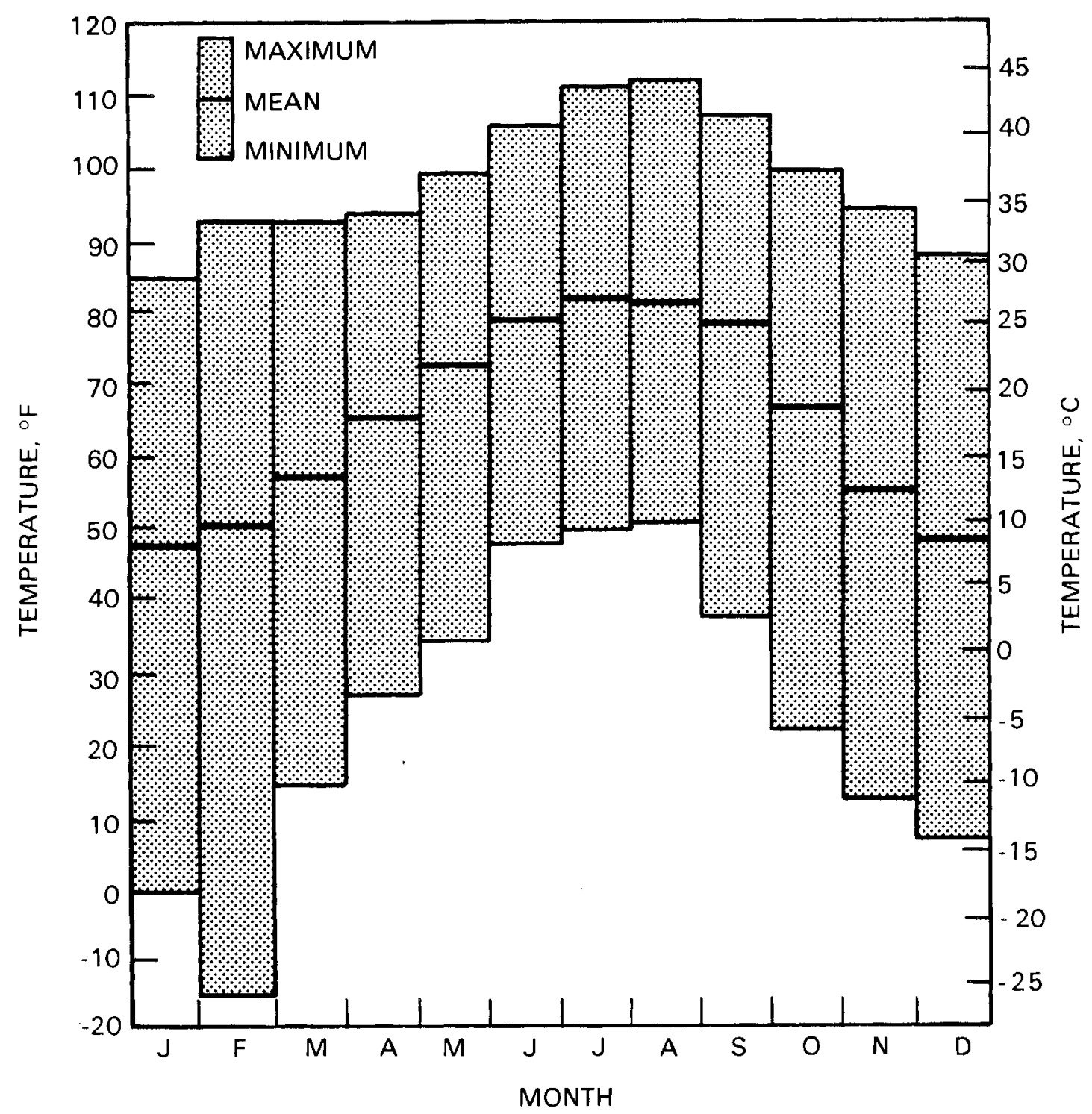

FIGURE 25. Range of Temperature Near Vacherie Dome, Louisiana 


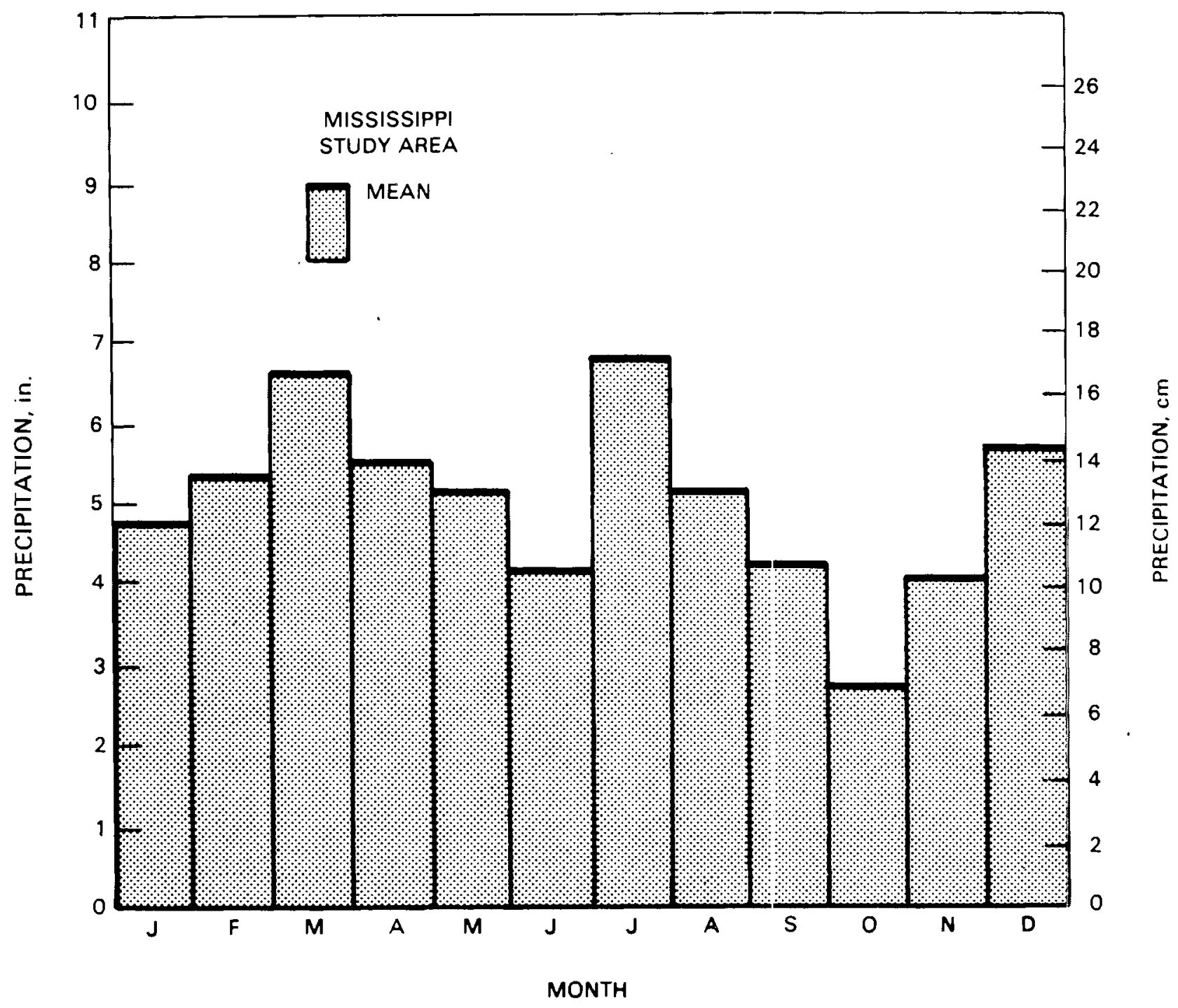

FIGURE 26. Range in Precipitation Near Richt:on Dome, Mississippi (Source: ONWI-193, Bechtel National 1982b) 


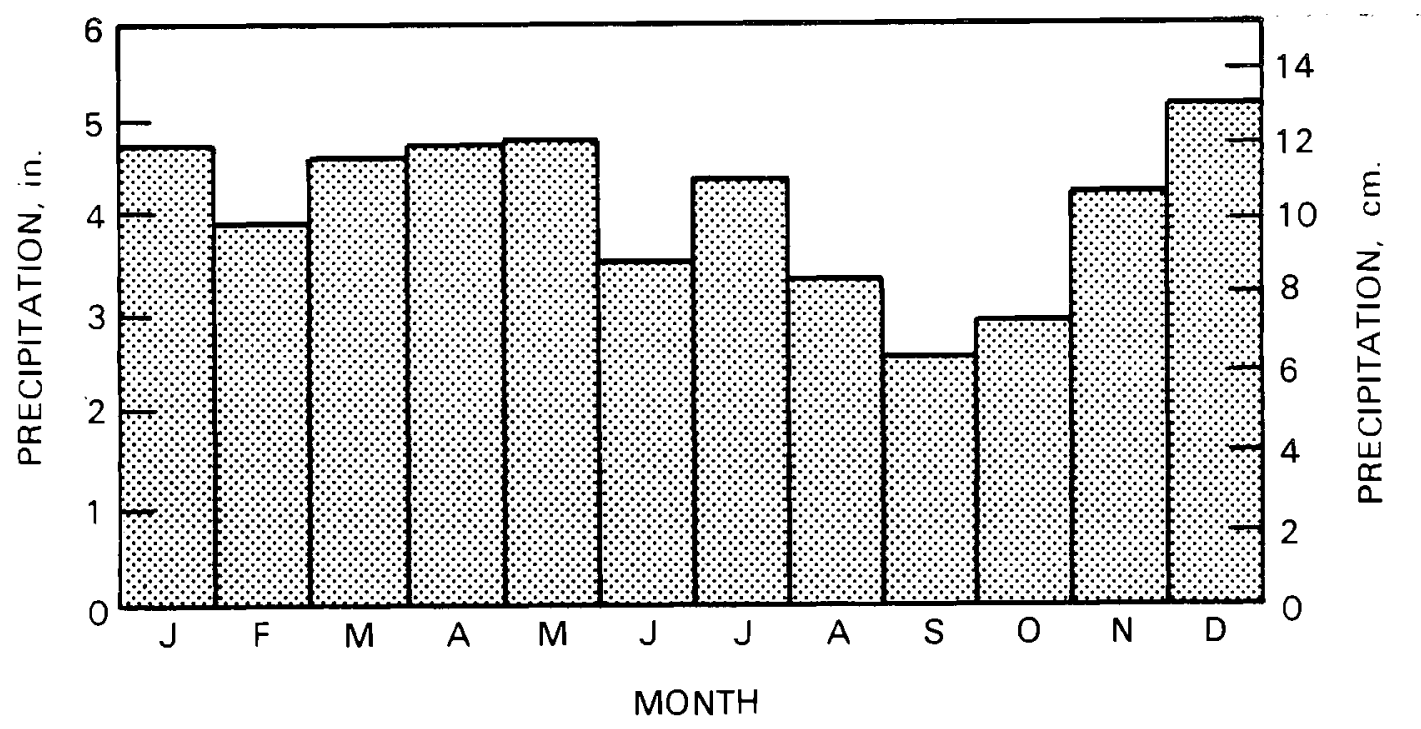

FIGURE 27. Range in Precipitation Near Vacherie Dome, Louisiana 
- 
POSSIBLE FUTURE CLIMATE CONDITIONS IN THE LOUISIANIA AND

MISSISSIPPI GULF COAST REGION

Previous sections present an argument for accepting the premise that the climate will return to a glacier ice age within the time of interest. Accepting this premise, the following discussion summarizes current ideas about the nature of climate during the last full glacier period. This is followed by an analysis of the implications that such a climatic change has for the potential nuclear waste repository.

Estimating past climatic changes in either Louisiana or Mississippi is difficult because compared to the other areas, neither has been extensively studied. Further, Barry (1983) points out that the literature reveals considerable disagreement over the extent of vegetational and climatic changes that occurred during the last glaciation in the eastern and southeastern United States. However, evidence exists that the glacier climate of the region was both drier and colder (Figure 3). For instance, in southern Alabama, Delcourt (1980) finds evidence of xeric oak-hickory forest during glacial times which suggest summer drought stress. Watts (1975, 1980) and Watts and Stuiver (1980) also identify very dry conditions in Florida between 37,000 and 13,000 year B.P., with xeric shrubs and only a few trees present. During the full glacial in Tennessee, Delcourt (1979) estimates that mean annual precipitation may have been reduced by more than half, and mean annual temperatures by as much as $15^{\circ} \mathrm{C}$ from today's values.

Given the lack of quantitative paleoclimatic studies in either Louisiana or Mississippi, the best approach appears to be to estimate a range of possible changes using results from studies of surrounding areas. Using this approach, precipitation could possibly range from double the present amount [using data from Reeves (1973), see section on possible future climate conditions at the palo Duro Basin] to one-half the present amount [using the values of precipitation found by Delcourt (1979) in Tennessee]. 
. 


\section{ANALYSIS FOR THE LOUISIANA AND MISSISSIPPI GULF COAST REGION}

If Reeves (1966) estimation for a doubling of precipitation is used, then several reasons suggest that it would be conservative to say that recharge also doubled. Evidence for this premise is listed below.

1. A new glacier age may not occur during the 10,000-year time period of interest. For instance, workers in the field (e.g., Emiliani 1972; Morner 1972) suggest that a new glacier ice age will not occur until after the 10,000-year time frame.

2. In general, it would be expected that this region would become drier (Figure 3) during a glacier age. It can be argued that using Reeves' (1966) estimate is extremely conservative in that 1) Reeves work was done at a site a considerable distance away from the study, 2) sites much closer (e.g., Alabama and Florida) indicate a drier climate during glacier times, and 3) if the current precipitation were to double, a very high value would result, comparable to only a few locations in the United States today.

3. The relatively high values of precipitation today suggest that the groundwater system may be saturated.

4. As mentioned before, recharge is not just a simple linear function of rainfall, but also a function of other factors such as new vegetation. However, as seen in the previous cases, the biosphere may well adjust to take advantage of the new water, rather than let all of it pass into the ground.

If recharge is doubled, then in general, it would be expected that the water table would rise and the velocities of the ground water may increase. However, both geologic intuition and modeling results suggest that, in large part because of the low permeability of the salt, the integrity of a repository would not be effected. 
Estimates of sea level changes are relatively easier to make for several reasons:

1. The relationship between ice volume and sea level drop is well known.

2. A considerable body of literature is available on the subject.

3. It is much safer to extrapolate the results from other locations in the world to the area on sea level changes, than changes in climate.

Sea level could possibly rise or fall during the next 10,000 years. Within the present interglacial period, there is a small chance that the Antarctic and the Greenland ice sheets could melt. Such melting would raise the sea level by 60 to $70 \mathrm{~m}$ (Hollin 1962). With the growth of glaciers, sea level would fall. Reconstructions of the Wisconsin ice sheets in North America (Sugden 1977; CLIMAP Project 1976) when extended to other parts of the northern hemisphere, indicate a minimum sea level drop of $126 \mathrm{~m}$ and a maximum drop of about $165 \mathrm{~m}$ (Bull 1979) 18,000 years ago.

A return of the glaciers also implies a lowering of sea level. A change in sea level would affect the hydraulic gradient. However, the total effect is not expected to be large. The current lateral distance over which any ground water moves to the ocean is large compared to the change in sea level. Further, because the coastal waters are shallow, the shoreline will move far to the south as sea level drops. Hence, an increase in travel distance can partially compensate for the increase in head difference. Again, because the salt has such low permeability, these small changes are not expected to significantly alter the integrity of the repository horizon. However, modeling is needed to check this qualitative argument.

With a lowering of sea level, the surface-water system could be expected to respond with increasing erosion as a consequence of streams responding to a change in base level with falling sea levels. However, Aronow (1982) has shown that even with extremely conservative assumptions about the nature of this increased erosion, the dome would not be exposed by this new erosion.

Inundation of the area is conceivable if all the ice in the world were to melt. Total inundation may have favorable consequences because it would tend to destroy the ground-water gradient and inhibit erosion. However, modeling is 
needed to further explain the effects of such flooding. For instance, what changes are introduced by having a two phase system (i.e., salt and fresh water). If the area were only partially covered, it would be subject to erosion from wave action. In this case, the maximum probable reduction of land surface by wave erosion would be on the order of $6 \mathrm{~m}$ (Aronow 1982). 
Several lines of reasoning were presented that argue that the world may enter a new glacier climatic state within the next 10,000 years. If this occurs, conservative estimates suggest that the Palo Duro and Gibson Dome region may experience roughly a doubling of precipitation and a temperature decrease in the order of $10^{\circ} \mathrm{C}$. Although a reasonable amount of evidence suggests that the Gulf Coast region may become drier (Figure 3 ) during glacial times, lack of quantitative estimates for paleoclimatic conditions in Louisiana and Mississippi proper necessitated using the conservative assumption that precipitation also increased in this area during glacier times. During the next 10,000 years sea level also may change.

Although the effects of climate change at the surface for all three areas were not found to be a danger to a repository located at the currently planned depths (i.e., on the order of $1,000 \mathrm{~m}$ ) the effects of climate change on the ground-water system needs further study. For the Gulf Coast area, a qualitative argument was made that changing sea level would not significantly perturb the ground-water system with respect to the repository. However, modeling experiments would be useful to provide a quantitative check for these arguments. For both the Palo Duro and Gibson Dome areas, several considerations were put forward which suggest that a change to a glacial climate will not significantly affect the repository integrity. However, accurate estimates are needed of recharge to the ground-water system during glacial times. Then ground-water models can be used to obtain a quantitative measure of the possible effect of this increased recharge.

To deal with the uncertainty in recharge during glacial times at both the Palo Duro and Gibson Dome sites, three possible approaches are suggested:

1. Determine if the system is insensitive to recharge (i.e., the question of uncertainty in recharge is not crucial). If the system is insensitive to recharge, then model runs should be able to demonstrate this by showing that when obviously upper-bound recharge values are used as boundary conditions, the changes in the ground-water flow do not significantly affect the repository system. Given the low permeability of the salt, it may 
well be that the system is indeed insensitive to changes in recharge and thus this approach may be the fastest and easiest way to an acceptable resolution.

2. Find and analyze a natural analog. In this report, an estimation of temperature, precipitation, and vegetation is given for a future glacial climate. Soil type is known. Thus, if a location can be found that roughly matches these conditions, and the recharge determined for that situation, future recharge at the site could be estimated. This empirical approach might well be the easiest to defend.

3. Use models. Several unsaturated ground-water models are available that can provide an estimate of recharge. Again an estimation of future temperature, precipitation, and vegetation is given, which can be used in developing the necessary data input. 


\section{REFERENCES}

Antevs, E. 1952. "Cenozoic Climates of the Great Basin." Geologischen Rundschau 40:94-108.

Antevs, E. 1954. "Climate of New Mexico During the Last Glacio-Pluvial." Journal of Geology 62:182-191.

Aronow, S. 1982. Maximum Potential Erosion and Inundation of Seven Salt Domes. ONWI-278, prepared for Office of Nuclear Waste Isolation, Battelle Memorial Institute, Columbus, Ohio.

Bachhumber, F. W. and W. A. McClellan. 1977. "Paleoecology of Marine Foraminifera in Pluvial Estancia Valley, Central New Mexico." Quaternary Research 7:254-267.

Barry, R. G. 1983. "Late Pleistocene Climatology." In Late Quaternary Environment of the United States, ed. H. E. Wright, Jr. pp. 390-407 of Vol. 1, The Late Pleistocene ed. S. C. Porter, University of Minnesota Press, Minneapolis.

Bechtel National. 1982a. Environmental Characterization Report for the Paradox Basin Study Region, Utah Study Areas. ONWI-144, prepared for office of Nuclear Waste Isolation, Battelle Memorial Institute, Columbus, Ohio.

Bechtel National. 1982b. Environmental Characterization Report for the Gulf Interior Region Mississippi Study Area. ONWI-193, prepared for Office of Nuclear Waste Isolation, Battelle Memorial Institute, Columbus, onio.

Berger, A. L. 1978. "Long-Term Variations of Coloric Insolation Resulting from the Earth's Orbital Elements," Quaternary Research :139-167.

Betancourt, J. L. and N. E. Biggar. 1984. Preliminary Assessment of Late Quaternary Vegetation and Climate of Southeastern Utah Based on Analysis of Pack-Rat Middins. Topical Report prepared by Woodward-Clyde Consultants for the Office of Nuclear Waste Isolation, Battelle Memorial Institute, Columbus, Ohio.

Biggar, N. E., D. R. Harden and M. L. Gillan. 1981. "Quaternary Deposits of the Paradox Basin." In Geology of the Paradox Basin, ed. D. L. Wiegand, pp. 129-145, Rocky Mountain Association of Geologists, Denver, Colorado.

Brackenridge, G. R. 1978. "Evidence for a Cold, Dry Full-Glacial Climate in the American Southwest." Quaternary Research 9:22-40.

Broecker, W. S. and P. C. Orr. 1958. "Radiocarbon Chronology of Lake Lahontan and Lake Bonneville." Geological Society of America Bulletin 69:1009-1032. 
Bryson, R. A. and W. P. Lowry. 1955. "The Synoptic Climatology of the Arizona Summer Precipitation Singularity." American Meteorological Society Bulletin $36: 329-339$.

Bul1, C. 1979. "Glaciological Parameters of Disruptive Event Analysis." In A Suminary of FY-1978 Consultant Input for Scenario Methodology Development, eds. B. L. Scott, G. L. Benson, R. A. Craig, M. A. Harwel1, PNL-2851, Pacific Northwest Laboratory, Richland, Washington.

Cess, R. D. and J. C. Wronka. 1979. "Ice Ages and the Milankovitch Theory: A Study of Interactive Climatic Feedback Mechanisms." Tellus 31:185-192.

CLIMAP Project. 1976. "The Surface of the Ice-Ages Earth." Science $191: 1131-1137$.

Cole, K. 1980. Late Pleistocene and Holocene Vegetational Gradients in the Grand Canyon Arizona. American Quaternary Assoc ation, Abstracts with Programs, Sixth Bienniai Meeting. p. 57.

Covey, C. 1984. "The Earth's Orbit and the Ice Age." Scientific American, $250:(2) 58-66$.

Croll, J. 1875. Climate and Time in their Geological Relations: A Theory of Secular changes of the Earth's Climate. 4th Ed. (1890), London.

Daubenmire, R. 1954. "Alpine Timberlines in the Americas and Their Interpretation." Butler University Botanical Studies 11:119-136.

Delcourt, H. R. 1979. "Late Quaternary Vegetational History of the Eastern Highland Rim and Adjacent Cumberland Plateau of Tennessee." Ecological Monographs 49:255-280.

Delcourt, P. A. 1978. Quaternary Vegetation History of the Gulf Coastal Plain. Ph.D Thesis, University of Minnesota.

Delcourt, P. A. 1980. "Goshen Springs: Late Quaternary Vegetation Record for Southern Alabama." Ecology 61:371-386.

Delcourt, P. A. and H. R. Delcourt. 1977. "The Tuncia Hills, LouisianaMississippi: Late Glacial Locality For Spruce and Deciduous Forest Species." Quaternary Research 7:218-237.

Delcourt, P. A., et al. 1980. "Quaternary Vegetation History of the Mississippi Embayment." Quaternary Research 13:111-132.

DOE. 1983. "U.S. Department of Energy, 10 CFR 960, General Guidelines for Recommendations of Sites for Nuclear Waste Repositories." 10 CFR 960, Draft Final Guidelines prepared by the Department of Energy, August 1, 1983. 
Dougherty, J.P. 1979. Suspended-Sediment Load of Texas Streams: Compilation Report, October 1971 - September 1975. Texas Dept. Water Resources, Report No. 233, p. 83 .

Emiliani, C. 1972. "Quaternary Hypsithermals." Quaternary Research $2: 341-349$.

Fairbridge, R. W. 1970. "World Paleoclimatology of the Quaternary: Rev de Geog." Phys. Et de Geol. Dynam. 12:97-104.

Finley, R. J. 1979. "Climate of the Texas Panhandle and Its Influence on Erosion." Texas Bur. Econ. Geol., Geol. Circ. 79(1):65-68.

Finley, R. J. 1980. "Climatic Analysis." Texas Bur. Econ. Geol., Geol. Circ. $80(7): 52-57$.

Finley, R. J. and T. C. Gustavson. 1980. "Climatic Controls on Erosion in the Rolling Plains and Along the Caprock Escarpment of the Texas Panhandle." Texas Bur. Econ. Geol., Geol. Circ. 80(11):50.

Flint, R. F. 1971. Glacial and Quaternary Geology. John Wiley \& Sons, Inc., New York.

Flohn, H. 1978. "Background of a Geophysical Model of the Initiation of the Next Glaciation." In Climatic Change, ed. J. \#\#Gribbinm, pp. 249-265, Cambridge University Press, Cambridge, England.

Frenzel, B. 1973. Climatic Fluctuations of the Ice Age. Trans. A.E.M. Nairn, 306 p., Case Western Reserve University Press, Cleveland, Ohio.

Galloway, R. W. 1970. "The Full-Glacial Climate in the Southwestern United States." Ann Assoc. Amer. Geographers 60:245-256.

Galloway, R. W. 1983. "Full-Glacial Southwestern United States: Mild and Wet or Cold and Dry." Quaternary Research 19:236-248.

Griggs, R. F. 1946. "The Timberlines of North America and Their Interpretation." Ecology $27: 275-289$.

Grove, A. T. 1968. "The Last 20,000 Years in the Tropics." Brit. Geomorph. Research Group Assos. Paper 5:51-62.

Hafsten, U. 1961. "Pleistocene Development of Vegetation and Climate in the Southern High Plains as Evidenced in Pollen Analysis." In Paleoecology of the Llano Estacado ed. F. Wendorf, p. 59-99, Museum of New Mexico Press, Santa Fe, New Mexico.

Hales, J. E., Jr. 1974. "Southwestern United States Summer Monsoon Source Gulf of Mexico or Pacific Ocean?" Journal of Applied Meteorology 13:331-342. 
Haragan, D. R. 1976. "Spatial Variation of Precipitation on the Texas High Plains." Texas Water Devel. Board 111:125.

Haragan, D. R. 1978. "Precipitation Climatology for the Texas High Plains." Texas Jour. Sci. 30:107-123.

Harland, W. B. and K. N. Herod. 1975. "Glaciation Through Time." In Quaternary Geology and Climate, ed. H. E. Wright, pp. 141-450, National Academy of Sciences, Washington, D.C.

Hastings, J. R. and R. M. Turner. 1965. "The Changing Mile." University of Arizona Press, Tucson, Arizona.

Hays, J. D., et al. 1976. "Variations in the Eartih's Orbit: Pacemaker of the Ice Ages." Science 194:141-450.

Hollin, J. T. 1962. "On the Glacial History of Antarctica." Journal of Glaciology $4: 173-195$.

Imbrie, J. and K. P. Imbrie. 1979. Ice Ages, Solving the Mystery. Enslow Pub., Short Hills, New Jersey.

Imbrie, J. and K. P. Imbrie. 1980. "Modeling the Climatic Response to Orbital Variations." Science $207: 943-953$.

John, B. S. 1979a. "Planet Earth and Prediction." In The Winters of the World, pp. 219-231, Halstead Press, New York.

John, B. S. 1979b. "Planet Earth Its Seasons of Cold." In The Winters of the World, pp. 9-29, Halstead Press, New York.

Kukla, G. 1978. "Probability of Expected Climate Stresses in North America in the Next One Million Years." In Summary of FY-1978 Consultant Input for Scenario Methodology Development, eds. B. L. Scott, G. L. Benson, R. A. Craig, M. A. Harwell, PNL-2851, Pacific Northwest Laboratory, Richland, Washington.

Kukla, J., R. K. Matthews and J. M. Mitchell, Jr. 1972. "The End of the Present Interglacial." Quaternary Research 2(2):261-269.

Langbein, W. B. and S. A. Schumm. 1958. "Yield of Sediment in Relation to Mean Annual Precipitation." Am. Geophys. Union Trans. 39:1076-1084.

Lanner, R. M. and T. R. Van Devender. 1981. "Late Pleistocene Pinon Pines in the Chihuahuan Desert." Quaternary Research 15:278-290.

Leopold, L. B. 1951. "Pleistocene Climate in New Mexico." Am. Jour. Science 249:152-168. 
Mifflin, M. D. and M. M. Wheat. 1979. "Pluvial Lakes and Estimated Pluvial Climates of Nevada." Nevada Bureau of Mines and Geology Bulletin 94.

Milankovitch, M. 1920. Theorie Mathematique des Phenomenes Thermiques Produits par la Radiation Solaire. Gauthier-Villars, Paris, 339 p.

Mitche11, J. M., Jr. 1977a. "The Changing Climate." Chapter 2 In Energy and Climate, National Academy of Sciences, Washington, D.C.

Morner, N. A. 1972. "When Will the Present Interglacial End?" Quaternary Research 2:341-349.

Morrison, R. B. 1965. "Quarternary Geology of the Great Basin." In The Quarternary of the United States, H. E. Wright, Jr., and D. G. Frey, eds., pp. 265-285, Princeton University Press, Princeton, New Jersey.

NOAA (National Dceanic and Atmospheric Administration). 1974. Climates of the States Vol. II. U.S. Department of Commerce, Washington, D. C.

NOAA (National Oceanic and Atmospheric Administration). 1981. Local Climatological Data, Annual Summaries for 1980, Part II - Nebraska--Wyoming. National Climatic Center, Asheville, North Carolina.

Petrie, G. M., et al. 1981. Geologic Simulation Model for a Hypothetical Site in the Columbia Plateau. PNL-3542, Pacific Northwest Laboratory, Richland, Washington.

Reeves, C. C., Jr. 1965. "Pleistocene Climate of the Llano Estacado." J. of Geology 73:181-189.

Reeves, C. C., Jr. 1966. "Pleistocen Climate of the Llano Estacado." Journal of Geology. $74: 642-647$.

Reeves, C. C., Jr. 1973. "The Full-Glacial Climate of the Southern High Plains, West Texas." J. of Geology $81: 693-704$.

Reeves, C. C., Jr. 1976. "Quaternary Stratigraphy and Geologic History of Southern High Plains of Texas and New Mexico." In Quaternary Stratigraphy of North America, ed. W. C. Mahaney, pp. 213-234.

Schumm, S. A. 1965. "Quarternary Paleohydrology." In The Quarternary of the United States, H. E. Wright and D. G. Frey, eds., pp. 783-794, Princeton University, Press, Princeton, New Jersey.

Smagorinsky, J., et al. 1982. Carbon Dioxide and Climate: A Second Assessment. Report of the $\mathrm{CO}_{2} / \mathrm{Cl}$ imate Review Panel to the National Research $\overline{C o u n c i 1 . ~ N a t i o n a l ~ A c a d e m y ~ P r e s s, ~ W a s h i n g t o n, ~ D . C . ~}$ 
Smith, G. I. and F. A. Street-Perrott. 1983. "Pluvial Lakes of the Western United States" In Late Quaternary Environments of the United States, ed. H. E. Wright, Jr., pp. 259-293, Vol. 1, The late Pleistocene, ed. S. C. Porter, University of Minnesota Press, Minrieapolis, Minnesota.

Snyder, C. T. and W. B. Langbein. 1962. "The Pleistocene Lake in Spring Valley, Nevada and Its Climatic Implications." Journal Geophysical Research $67: 2365-2395$.

Spaulding, W. G. 1977. "Late Quaternary Vegetational Change in the Sheep Range, Southern Nevada." Journal Arizona Academy' Sciences 12:3-8.

Spaulding, W. G. 1980. "The Changing Vegetation of a Southern Nevada Mountain Range." Ph.D. Dissertation, University of Arizona, Tucson, Arizona.

Spaulding, W. G., Leopold, E. B. and T. R. Van Devender. 1983. "Late Wisconsin Paleoecology of the American Southwest." In Late Quaternary Environments of the United States, ed. H. E. Wright, Jr., pp. 259-293, Vol. 1, The Late Pleistocene, ed. S. C. Porter, University of Minnesota Press, Minneapolis, Minnesota.

Sugden, D. E. 1977. "Reconstruction of the Morphology, Dynamics and Thermal Characteristics of the Laurentide Ice Sheet at It:s Maximum." Arctic and Alpine Research 9:21-47.

Tien, Pei-lin, F. B. Nimick, A. B. Muller, P. A. Davis, R. V. Gustavson, L. E. Duda and R. L. Hunter. 1983. Repository site Data and Information in Bedded Salt: Palo Duro Basin, Texas. NUREG/CR-3129, Sandia National Laboratories, Albuquerque, New Mexico.

Todd, D. K., ed. 1972. The Water Encyclopedia. 'Nater Information Center, Port Washington, New York.

Van Devender, T. R. 1977. "Holocene Woodlands in the Southwestern Deserts." Science 198:189-192.

Van Devender, T. R. and W. G. Spaulding. 1979. "Jevelopment of Vegetation and Climate in the Southwestern United States." Science 204:701-710.

Van Devender, T. R. and F. M. Wiseman. 1977. "A Preliminary Chronology of Bioenvironmental Changes During the Paleoindian Period in the Monsoonal Southwest." In Paleoindian Lifeways ed., E. Johnson, pp. 13-27, Museum Journal 17, West Texas Museum Association.

Wardle, P. 1965. "A Comparison of Alpine Timberlines in New Zealand and North America." New Zeal and Journal of Botany 3:113-135.

Watts, W. A. 1975. "A Late Quaternary Record of Vegetation from Lake Annie, Southcentral Florida" Geology 3:344-346. 
Watts, W. A. 1980. "The Last Quaternary Vegetation History of Southeastern United States." Annual Review of Ecology and Systematics 11:387-409.

Watts, W. A. and M. Stuiver. 1980. "Late Wisconsin Climate of Northern Florida and the Origin of Species-Rich Deciduous Forest." Science 210:325-327.

Wells, P. V. 1966. "Late Pleistocene Vegetation and Degree of Pluvial Climatic Change in the Chihuahuan Desert." Science 153:970-975.

Wells, P. V. 1979. "An Equable Glaciopluvial in the West: Pleniglacial Evidence of Increased Precipitation on a Gradient From the Great Basin to the Sonoran and Chihuahuan Deserts." Quaternary Research 12:311-325.

Wendorf, F. 1961. Paleoecology of the Llando Estacado. Museum of New Mexico Press, Santa Fe, New Mexico.

Wendorf, F. and J. J. Hester. 1975. "Late Pleistocene Environments of the Southern High Plains." Pub. 9, Ft. Bugwin Research Center.

Williams, J. 1975. "The Influences of Snowcover on the Atmosphere Circulation and Its Role in Climate Change: An Analysis Based on Results from the NCAR Global Circulation Model." Jour. App. Meteorology 14:137-152.

Williams, J., et al. 1974. "Simulation of the Atmospheric Circulation Using the NCAR Global Circulation Model with Ice Age Boundary Conditions." Jour. App. Meteorology 13:305-317.

Winograd, I. J. and G. C. Doty. 1980. Paleohydrology of the Southern Great Basin, With Special Reference to Water Table Fluctuations Beneath the Nevada Test Site During The Last(?) Pleistocene. U.S.G.S. Open-File Report 80-569.

WCC (Woodward-Clyde Consultants). 1982. Geological Characterization Report for the Paradox Basin Study Region, Utah Study Area. ONWI-290, prepared for the office of Nuclear Waste Isolation, Battelle Memorial Institute, Columbus, onio.

Wright, A. E. and F. Moseley. 1975. "Ice Ages: Ancient and Modern - A Discussion." In Ice Ages: Ancient and Modern, eds. A. E. Wright and F. Mosely, pp. 301-312, Seat House Press, Liverpool, England. 


\section{APPENDIX A}

GENERAL GUIDELINES FOR CLIMATE 
, 
GENERAL GUIDELINES FOR CLIMATE

The following two pages are an extract from the Draft Revised General Guidelines for Recommendation of Sites for Nuclear Waste Repositories (DOE 1983) that deals with climatic changes.

960.4 Postclosure Guidelines

960.4.1 System Guidelines

The geologic repository shall physically separate the radioactive waste from the accessible environment. The site, as supplemented by engineered systems, shall provide reasonable expectation that after the closure of the repository, postulated releases of radioactive materials will be kept within the limits specified in 40 CFR 191, Subpart E, Environmental Standards of Disposal, and shall meet the requirements of 10 CFR 60 , Subpart $E$, Technical Criteria.* A site shall be disqualified if the characteristics that influence radionuclide transport do not allow reasonable expectation of compliance with 40 CFR 191, Subpart B, when considered in conjunction with engineered barrier systems, including those required under 10 CFR 60.113.

\footnotetext{
*Proposed 40 CFR 191, Subpart B, would require that for 10,000 years, releases of radioactive materials to the accessible environment that are estimated to have more than one chance in 100 of occurring over a 10,000 year period ("reasonably foreseeable releases") shall be projected to be less than the quantites permitted by Table 2 of that regulation's Appendix. For "very unlikely releases" (i.e., those estimated to have between one chance in 100 and one chance in 10,000 of occurring over a 10,000 year period), the limits specified in Table 2 would be multiplied by 10 .
}

Proposed 10 CFR 60.112 would implement 40 CFR 191. 10 CFR 60.113 would further establish minimum conditions to be met for engineered components and ground-water flow.

These guidelines will be updated as required following the adoption of final regulations by the NRC and the EPA. 
960.4.2.4 Climatic Changes

The site shall be located where future climatic conditions are such that any radionuclide releases resulting from climatic conditions would meet the requirements specified in Section 960.4.1.

(a) Favorable Conditions

(1) A surface-water system such that expected climatic cycles will not cause unacceptable impacts on waste isolation.

(2) A geologic setting in which the clinate and hydrologic system have remained relatively constant throughout the Quaternary period.

(b) Potentially Adverse Conditions

(1) Evidence that the water table might rise sufficiently to saturate a previously unsaturated host rock.

(2) Evidence that changes in geohydrologic conditions due to climatic changes could cause perturbations in the hydraulic gradient, the hydraulic conductivity, the effective porosity, and the groundwater flux through the host rock sufficient to significantly increase the transport of radionuclides to the accessible environment.

\section{REFERENCES}

DOE. 1983. "U.S. Department of Energy, 10 CFR 961, General Guidelines for Recommendations of Sites for Nuclear Waste Repositories." 10 CFR 960, Draft Final Guidelines prepared by the Department of Energy, August 1, 1983. 
DISTRIBUTION

No. of

Copies

OFFSITE

5 A. Gupta

Battelle Memorial Institute

Office of Nuclear Waste

Isolation

$505 \mathrm{King}$ Avenue

Columbus, $\mathrm{OH} 43201$

10 Battelle Memorial Institute Office of Nuclear Waste Isolation

Attn: Beverly Rawles

505 King Avenue

Columbus, $\mathrm{OH} 43201$

James 0. Duguid

Battelle Memorial Institute

Office of Nuclear Waste

Isolation

505 King Avenue

Columbus, $\mathrm{OH} 43201$

William M. Hewitt

Battelle Memorial Institute

Office of Nuclear Waste

Isolation

505 King Avenue

Columbus, $\mathrm{OH} \quad 43201$

Peter L. Hofmann

Battelle Memorial Institute

office of Nuclear Waste Isolation

505 King Avenue

Columbus, $\mathrm{OH} \quad 43201$

Muzaffer Kehnemuyi

Battelle Memorial Institute

Office of Nuclear Waste

Isolation

505 King Avenue

Columbus, $\mathrm{OH} 43201$
No. of

Copies

John F. Kircher

Battelle Memorial Institute

Office of Nuclear Waste

Isolation

$505 \mathrm{King}$ Avenue

Columbus, $\mathrm{OH} 43201$

Gilbert E. Raines

Battelle Memorial Institute

Office of Nuclear Waste

Isolation

$505 \mathrm{King}$ Avenue

Columbus, $\mathrm{OH} 43201$

D. B. Shipler

Battelle Memorial Institute

Office of Nuclear Waste

Isolation

505 King Avenue

Columbus, $\mathrm{OH} 43201$

27 DOE Technical Information Center

W. W, Ballard

DOE Office of Nuclear Waste Management

Washington, DC 20545

Carl R. Cooley

DOE Office of Nuclear Waste

Management

Washington, DC 20545

ONSITE

DOE Richland Operations office

H. E. Ransom 
No. of

Copies

29 Pacific Northwest Laboratory

C. R. Cole

J. L. Devary

J. L. Downs-Berg

D. W. Dragnich

M. G. Foley

P. C. Hays

M. R. Kreiter

G. M. Petrie (10)

G. Stokes

J. A. Stottlemeyer

F. L. Thompson (3)

Publishing Coordination (2)

Technical Information (5) 